\title{
Article \\ Plasmonic Au-Pd Bimetallic Nanocatalysts for Hot-Carrier-Enhanced Photocatalytic and Electrochemical Ethanol Oxidation
}

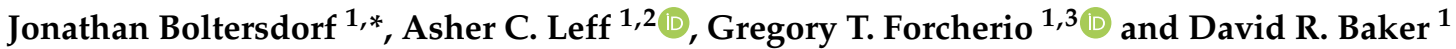 \\ 1 United States Army Research Laboratory, Sensors and Electron Devices Directorate, Adelphi, MD 20783, USA; \\ asher.c.leff.ctr@mail.mil (A.C.L.); gregory.forcherio@navy.mil (G.T.F.); david.r.baker175.civ@mail.mil (D.R.B.) \\ 2 General Technical Services, Wall, NJ 07727, USA \\ 3 Electro-Optic Technology Division, Naval Surface Warfare Center, Crane, IN 47522, USA \\ * Correspondence: jonathan.a.boltersdorf.civ@mail.mil
}

Citation: Boltersdorf, J.; Leff, A.C.; Forcherio, G.T.; Baker, D.R. Plasmonic $\mathrm{Au}-\mathrm{Pd}$ Bimetallic Nanocatalysts for Hot-Carrier-Enhanced Photocatalytic and Electrochemical Ethanol Oxidation. Crystals 2021, 11, 226. https://doi.org/10.3390/cryst11030226

Academic Editor: Duncan Gregory

Received: 22 January 2021

Accepted: 20 February 2021

Published: 25 February 2021

Publisher's Note: MDPI stays neutral with regard to jurisdictional claims in published maps and institutional affiliations.

Copyright: (c) 2021 by the authors. Licensee MDPI, Basel, Switzerland. This article is an open access article distributed under the terms and conditions of the Creative Commons Attribution (CC BY) license (https:/ / creativecommons.org/licenses/by/ $4.0 /)$.

\begin{abstract}
Gold-palladium ( $\mathrm{Au}-\mathrm{Pd}$ ) bimetallic nanostructures with engineered plasmon-enhanced activity sustainably drive energy-intensive chemical reactions at low temperatures with solar simulated light. A series of alloy and core-shell Au-Pd nanoparticles (NPs) were prepared to synergistically couple plasmonic $(\mathrm{Au})$ and catalytic $(\mathrm{Pd})$ metals to tailor their optical and catalytic properties. Metalbased catalysts supporting a localized surface plasmon resonance (SPR) can enhance energy-intensive chemical reactions via augmented carrier generation/separation and photothermal conversion. Titania-supported Au-Pd bimetallic (i) alloys and (ii) core-shell NPs initiated the ethanol (EtOH) oxidation reaction under solar-simulated irradiation, with emphasis toward driving carbon-carbon $(\mathrm{C}-\mathrm{C})$ bond cleavage at low temperatures. Plasmon-assisted complete oxidation of $\mathrm{EtOH}$ to $\mathrm{CO}_{2}$, as well as intermediary acetaldehyde, was examined by monitoring the yield of gaseous products from suspended particle photocatalysis. Photocatalytic, electrochemical, and photoelectrochemical (PEC) results are correlated with $\mathrm{Au}-\mathrm{Pd}$ composition and homogeneity to maintain SPR-induced charge separation and mitigate the carbon monoxide poisoning effects on Pd. Photogenerated holes drive the photo-oxidation of EtOH primarily on the Au-Pd bimetallic nanocatalysts and photothermal effects improve intermediate desorption from the catalyst surface, providing a method to selectively cleave $\mathrm{C}-\mathrm{C}$ bonds.
\end{abstract}

Keywords: plasmonic resonance; catalytic energy conversion; nanomaterials

\section{Introduction}

Efficient chemical transformations of readily available resources (solar energy, water, waste products, etc.) via light-energy conversion enables the generation of energy-dense fuels and electrical power [1-3]. Directed harvesting of solar energy can be facilitated by photocatalytic processes augmented by plasmon-mediated chemistry [3-8]. Plasmonic nanostructures ( $\mathrm{Au}, \mathrm{Ag}$ ) exhibit localized surface plasmon resonance (SPR), the coherent oscillation of conduction electrons coupled to strong local electric fields. Landau damping of the SPR (1-100 fs) promotes excitation of energetic, or "hot", charge carriers [3,8,9], in addition to increasing light absorption, enhancing far-field light scattering, and inducing charge separation in semiconductors [3,6,8-10]. Ohmic relaxation of "hot" electrons (100 fs to $1 \mathrm{ps)}$ results in local thermal dissipation (100 ps to $10 \mathrm{~ns}$ ) that can aid in activating adsorbed reactants and accelerating surface kinetics [3,9,10]. Emerging multifunctional photocatalysts incorporate both plasmonic and catalytic active materials for chemical conversion [3,5-16]. Coupling of plasmonic metals to semiconductors as a photosensitization strategy has demonstrably facilitated hot-carrier generation/separation $[6,7,11,12]$. Bimetallic nanocatalysts with a plasmonic component interact strongly with resonant photons, generating hot carriers at catalytically active noble metal sites to promote chemical transformations 
and enhance product selectivity [16-18]. Previous reports postulate that surface charge heterogeneity and transfer in bimetallic nanostructures can strengthen reactant adsorption, enhance product selectivity [4,5,19-21], and increase the rate of $\mathrm{H}_{2}$ production [4,22-29]. Strategically engineered bimetallic nanocatalysts present a transformative pathway to control electronic and optical properties to overcome current limitations in catalysis and selectively enhance reactions, such as the ethanol (EtOH) oxidation reaction (EOR).

$\mathrm{EtOH}$ is an attractive nontoxic chemical fuel owing to its existing supply chain, carbon-neutral production from agricultural biomass, high theoretical energy density $\left(\sim 8 \mathrm{kWh} \cdot \mathrm{kg}^{-1}\right)$, and simple storage and infrastructure [2,30-32]. Further, the EOR has the capability for $\mathrm{H}_{2}$ generation via catalytic deprotonation under neutral to acidic conditions. The desired EOR pathway is a high-energy $(\Delta \mathrm{G}=-1326.7 \mathrm{~kJ} / \mathrm{mol}), 12$-electron process that requires multiple electron transfer steps for the $\mathrm{C}_{1}$-overall reaction(s) in low and high $\mathrm{pH}[2]$ :

$$
\begin{gathered}
{[\text { Low pH }] \mathrm{CH}_{3} \mathrm{CH}_{2} \mathrm{OH}+3 \mathrm{H}_{2} \mathrm{O} \rightarrow 2 \mathrm{CO}_{2}+6 \mathrm{H}_{2}+12 \mathrm{e}^{-}} \\
{[\text {High pH }] \mathrm{CH}_{3} \mathrm{CH}_{2} \mathrm{OH}+16 \mathrm{OH}^{-} \rightarrow 2 \mathrm{CO}_{3}{ }^{2-}+11 \mathrm{H}_{2} \mathrm{O}+12 \mathrm{e}^{-}}
\end{gathered}
$$

Breaking the carbon-carbon $(\mathrm{C}-\mathrm{C})$ bond has been found to be the rate-limiting step, as the EOR is interrupted by the production of two $\mathrm{C}_{2}$-intermediates: acetaldehyde $\left(\mathrm{CH}_{3} \mathrm{CHO}\right.$, $\left.n=2 \mathrm{e}^{-}\right)$first, and then further by acetic acid $\left(\mathrm{CH}_{3} \mathrm{COOH}, n=4 \mathrm{e}^{-}\right)$. The $\mathrm{C}_{2}$-intermediate(s) can obstruct active sites by adsorbing in inactive orientations and possess high energetic barriers for cleaving the $\mathrm{C}-\mathrm{C}$ bond $(>1.0 \mathrm{eV})$; limiting further oxidation [30,32-34].

$$
\begin{gathered}
{[\text { Low pH }] \mathrm{CH}_{3} \mathrm{CH}_{2} \mathrm{OH} \rightarrow \mathrm{CH}_{3} \mathrm{CHO}+2 \mathrm{H}^{+}+2 \mathrm{e}^{-}} \\
\mathrm{CH}_{3} \mathrm{CH}_{2} \mathrm{OH}+\mathrm{H}_{2} \mathrm{O} \rightarrow \mathrm{CH}_{3} \mathrm{COOH}+4 \mathrm{H}^{+}+4 \mathrm{e}^{-} \\
{[\mathrm{High} \mathrm{pH}] \mathrm{CH}_{3} \mathrm{CH}_{2} \mathrm{OH}+2 \mathrm{OH}^{-} \rightarrow \mathrm{CH}_{3} \mathrm{CHO}+2 \mathrm{H}_{2} \mathrm{O}+2 \mathrm{e}^{-}} \\
\mathrm{CH}_{3} \mathrm{CH}_{2} \mathrm{OH}+5 \mathrm{OH}^{-} \rightarrow \mathrm{CH}_{3} \mathrm{COO}^{-}+4 \mathrm{H}_{2} \mathrm{O}+4 \mathrm{e}^{-}
\end{gathered}
$$

Alkaline media $(\mathrm{pH} \geq 14)$ enables preferred deprotonation of the sterically hindered acetaldehyde intermediate to the $\left[\mathrm{CH}_{2} \mathrm{CHO}\right]^{-}$anion $\left(\mathrm{pK}_{\mathrm{a}}=13.6\right)$ and facilitates proper surface alignment for $\mathrm{C}-\mathrm{C}$ bond cleavage $[2,25,30,32,34]$. Therefore, the complexity of the EOR necessitates that the catalyst of interest can selectively activate $C-C$ bond cleavage for complete oxidation. The reaction rate for $\mathrm{Au}$ is dependent on the deprotonation step, whereas further oxidation is deterministic for catalytic metals (i.e., Pd). Therefore, Pd is one of the most active catalysts for the EOR, while $\mathrm{Au}$ is considered to have poor activity $[25,30,33,34]$. However, the catalytically active Pd lacks a strong SPR absorption for visible-light excitation and is susceptible to catalyst poisoning. Alloying or coupling Pd with plasmonic metals has shown improved catalytic reactivity compared to mono-metallic alternatives $[5,20,28]$, and is hypothesized to enhance the EOR activity.

The coupling of plasmonic and catalytic metals to semiconductive $\mathrm{TiO}_{2}$ is a costeffective alternative to using pure Pd catalysts to address challenges associated with product selectivity and total conversion of EtOH. This work leverages high-resolution electron imaging techniques (i.e., STEM), photocatalytic and PEC measurements of EOR, and discrete dipole approximation (DDA) computation to provide new, quantitative insights into understanding the role of plasmonic "hot" carriers in C-C bond cleavage during the EOR $[35,36]$. The synthetic preparation of bimetallic nanoparticles synergistically couples Au plasmonic absorbers with catalytic Pd, with the goal of tailoring their optical and catalytic properties. The effects of composition (i.e., $\mathrm{Au}_{1-x} \mathrm{Pd}_{x}$ ) and nanostructuring of the bimetallic nanoparticles (i.e., alloy vs. core-shell) on the plasmonic enhancement of the wide band gap $\mathrm{TiO}_{2}$ are presented. Low-temperature photo-oxidation of EtOH was studied via suspended particle photocatalysis and electrochemical methods, with EOR performance directly correlated to alloy homogeneity. Plasmonic catalyst structural and elemental morphologies were optimized to improve "hot" carrier generation and separation. 


\section{Materials and Methods}

\subsection{Chemicals}

Polyvinylpyrrolidone (PVP-40, 40,000 g/mol, Sigma-Aldrich, St. Louis, MI, USA), $\mathrm{H}_{2} \mathrm{PdCl}_{4}$ (99.999\%, Sigma-Aldrich), $\mathrm{HAuCl}_{4} \cdot 3 \mathrm{H}_{2} \mathrm{O}$ (99.999\%, Sigma-Aldrich), L-ascorbic acid (>99\%, Alfa Aesar, Ward Hill, MA, USA), $\mathrm{TiO}_{2}$ (P25 $\approx 25$ nm, Evonik, Essen, Germany), anhydrous ethyl alcohol (EtOH, 200 proof, Sigma-Aldrich), Vulcan XC-72 carbon black powder (Cabot, Boston, MA, USA), tert-butylamine (t-ButNH ${ }_{2}, \geq 99.0 \%$, Sigma-Aldrich), Nafion 117 solution (Nafion, 5\% in 1:1 EtOH: $\mathrm{H}_{2} \mathrm{O}$ ), $\mathrm{HClO}_{4}, \mathrm{HCl}$, and $\mathrm{KOH}$ were used as received, without further purification. Distilled, deionized water $(18.2 \mathrm{M} \Omega \cdot \mathrm{cm}$, EasyPure RF D7031) was utilized in all syntheses and measurements.

\subsection{Nanoparticle Synthesis}

\subsubsection{Gold-Palladium Alloys}

Gold-palladium bimetallic alloy nanoparticles $\left(\mathrm{Au}_{1-\mathrm{x}} \mathrm{Pd}_{\mathrm{x}} \mathrm{NPs}\right)$ were prepared with the compositions $\mathrm{Au}, \mathrm{Au}_{0.9} \mathrm{Pd}_{0.1}, \mathrm{Au}_{0.75} \mathrm{Pd}_{0.25}, \mathrm{Au}_{0.5} \mathrm{Pd}_{0.5}, \mathrm{Au}_{0.25} \mathrm{Pd}_{0.75}, \mathrm{Au}_{0.1} \mathrm{Pd}_{0.9}$, and $\mathrm{Pd}$ using a protocol reported in Reference [5]. First, the dark orange Pd precursor solution, $10 \mathrm{mM} \mathrm{H}_{2} \mathrm{PdCl}_{4}$, was prepared following our previously reported methodology [5,28]. Briefly, the desired compositions of the $\mathrm{Au}_{1-x} \mathrm{Pd}_{\mathrm{x}} \mathrm{NP}$ growth solutions were achieved by appropriately adjusting the mole ratio of $10 \mathrm{mM} \mathrm{HAuCl}{ }_{4} \cdot 3 \mathrm{H}_{2} \mathrm{O}$ and/or $10 \mathrm{mM} \mathrm{H}_{2} \mathrm{PdCl}_{4}$. Surfactant solution utilized to direct bimetallic alloy NP growth was $25 \mu \mathrm{M}$ PVP-40 in $20 \%$ $\mathrm{EtOH} / 80 \%$ deionized water. Precursors were combined with the surfactant solution to yield an orange-colored growth solution. A fresh solution of $0.100 \mathrm{M}$ ascorbic acid was prepared and $110 \mu \mathrm{L}$ was added to the growth solution as a weak reducing agent, which was stirred for $60 \mathrm{~min}$ at $100{ }^{\circ} \mathrm{C}$. The solution colors ranged from red to brown, yielding the desired $\mathrm{Au}_{1-\mathrm{x}} \mathrm{Pd}_{\mathrm{x}} \mathrm{NP}$ compositions [5].

\subsubsection{Gold-Palladium Core-Shells}

Similarly, the standard protocol previously reported in detail in Reference [5] was used for the growth of gold nanospheres (AuNSs) as starting materials for core-shell nanoparticles $\left(\mathrm{Au}_{\mathrm{Core}}-\mathrm{Au}_{1-\mathrm{x}} \mathrm{Pd}_{\mathrm{x}}\right.$.Shell $\left.\mathrm{NPs}\right)$. AuNSs were grown by combining $10 \mathrm{mM}$ $\mathrm{HAuCl}_{4} \cdot 3 \mathrm{H}_{2} \mathrm{O}$, the PVP-40 surfactant solution in $20 \% \mathrm{EtOH}$, and $110 \mu \mathrm{L}$ of $0.100 \mathrm{M}$ ascorbic acid, which was stirred for $60 \mathrm{~min}$ at $30^{\circ} \mathrm{C}$ to yield a red-colored AuNS solution. AuNSs were subsequently combined with $10 \mathrm{mM} \mathrm{H}_{2} \mathrm{PdCl}_{4}$ and $0.100 \mathrm{M}$ ascorbic acid for a $10 \mathrm{~mol} \%$ Pd shell loading ( $\mathrm{Au}_{\text {Core }}-10 \% \mathrm{Pd}_{\text {Shell }} \mathrm{NPs}$ ). Similarly, the AuNSs were combined with $10 \mathrm{mM} \mathrm{H}_{2} \mathrm{PdCl}_{4}, 10 \mathrm{mM} \mathrm{HAuCl} \cdot 3 \mathrm{H}_{2} \mathrm{O}$, and $0.100 \mathrm{M}$ ascorbic acid to yield a $10 \mathrm{~mol} \%$ $\mathrm{Au}_{0.5} \mathrm{Pd}_{0.5}$ shell loading ( $\mathrm{A} \mathrm{u}_{\mathrm{Core}}-10 \% \mathrm{AuPd}_{\text {Shell }} \mathrm{NPs}$ ). Solution changed from bright red to a darker red as $\mathrm{Pd}$ and $\mathrm{AuPd}$ shells formed on the $\mathrm{AuNSs}$. $\mathrm{Au}_{1-\mathrm{x}} \mathrm{Pd}_{\mathrm{x}}$ and $\mathrm{Au}_{\mathrm{Core}}{ }^{-}$ $\mathrm{Au}_{1-x} \mathrm{Pd}_{\mathrm{x}}$.Shell NPs were collected by a centrifugation and washing procedure $[5,6,28]$, followed by dispersion of the $\mathrm{Au}_{1-x} \mathrm{Pd}_{\mathrm{x}}$ and $\mathrm{Au}_{\mathrm{Core}}-\mathrm{Au}_{1-\mathrm{x}} \mathrm{Pd} \cdot \mathrm{x}$. Shell bimetallic NPs in $\mathrm{EtOH}$, which were stored in refrigeration.

\subsubsection{Deposition of Au-Pd on Catalyst Supports}

After purification, the $\mathrm{Au}-\mathrm{Pd} \mathrm{NP}$ samples were deposited onto $\mathrm{TiO}_{2}$ and carbon supports. $\mathrm{TiO}_{2}$ was mixed with $1 \mathrm{wt}$.\% Au-Pd NPs, sonicated to thoroughly disperse, and the well-mixed slurry was stirred for $48 \mathrm{~h}$. Au-Pd NPs dispersed on $\mathrm{TiO}_{2}$ were collected using a centrifugation and washing procedure (at $8500 \mathrm{rpm}$ for $45 \mathrm{~min}$ ). Supernatant was tested via ultraviolet-visible (UV-Vis) spectroscopy after washing to confirm the complete deposition of $\mathrm{Au}-\mathrm{Pd} \mathrm{NPs}$ onto $\mathrm{TiO}_{2}$. Samples were dried at $80^{\circ} \mathrm{C}$ for $24 \mathrm{~h}$ to remove excess solvent, yielding uniform powders ranging from purple to dark gray in color. Au-Pd NP samples were deposited onto XC-72 carbon supports via ligand-exchangeinduced destabilization. An NP loading of 1-20 wt.\% by total mass of $\mathrm{Au}$ and/or Pd (assuming a theoretical yield of 100\%) was used for each XC-72 support. XC-72 carbon powder was added to $15 \mathrm{~mL}$ of $\mathrm{t}-\mathrm{BuNH}_{2}$ and thoroughly dispersed via ultrasonication. Previously prepared $\mathrm{Au}-\mathrm{Pd} \mathrm{NP}$ samples were redispersed in EtOH, mixed with XC- 
$72 / \mathrm{BuNH}_{2}$ suspension, and stirred magnetically for $24 \mathrm{~h}$ for ligand exchange and NP deposition. Au-Pd NPs on carbon supports were isolated via $30 \mathrm{~mL}$ EtOH addition and centrifugation ( $8500 \mathrm{rpm}$ for $45 \mathrm{~min}$ ) and dried at $80^{\circ} \mathrm{C}$.

\subsubsection{Working Electrode Preparation}

Catalyst suspensions were prepared by dispersing the $\mathrm{TiO}_{2}$ - and carbon-supported $\mathrm{Au}-\mathrm{Pd}$ in 1:1 EtOH: $\mathrm{H}_{2} \mathrm{O}$ and $1 \mathrm{vol} \%$ Nafion solution via ultrasonication for $15 \mathrm{~min}$ to obtain a final catalyst concentration of $6 \mu \mathrm{g} \cdot \mu \mathrm{L}^{-1}$. The catalyst suspension $(10 \mu \mathrm{L})$ was drop-cast onto a glassy carbon electrode $\left(0.196 \mathrm{~cm}^{-2}\right)$. After excess solvent evaporation, $3 \mu \mathrm{L}$ of a diluted Nafion solution $(20 \% v / v$ in $\mathrm{EtOH})$ was deposited onto the catalyst layer to improve its physical stability and electrical conductivity. Electrode surfaces were allowed to completely dry prior to EOR electrochemical measurements.

\subsection{Characterization}

\subsubsection{UV-Vis Spectroscopy and Electron Microscopy}

Absorbance spectra collected from UV to near-infrared (NIR) for the $\mathrm{Au}_{1-x} \mathrm{Pd}_{x}$ and $\mathrm{Au}_{\text {Core }}-\mathrm{Au}_{1-\mathrm{x}} \mathrm{Pd}_{\mathrm{x}} \cdot$ Shell NPs in solution were obtained with an AvaSpec-ULS2048L spectrometer fiber-coupled deuterium and halogen light source, while diffuse reflectance measurements of the $\mathrm{Au}-\mathrm{Pd}$ on $\mathrm{TiO}_{2}$ powders required the addition of an Avasphere-30 PTFE integrating sphere. Bright-field TEM and high-angle annular dark-field imaging scanning TEM (HAADF-STEM) was performed in JEOL 2100F (Peabody, MA, USA) at $200 \mathrm{kV}$ equipped with an EDAX Octane T Optima system (Mahwah, NJ, USA) energy dispersive X-ray spectrometer (EDXS) to map the elemental distribution on the Au-Pd on $\mathrm{TiO}_{2}$ composites. Principal component analysis differentiated raw EDS spectra into six uncorrelated variables: $\mathrm{Au}, \mathrm{Pd}, \mathrm{Ti}, \mathrm{O}, \mathrm{C}$ (the support film), and background (surfactant, residual solvent, etc.). Samples were prepared by drop-casting onto solid carbon films for the $\mathrm{Au}_{1-\mathrm{x}} \mathrm{Pd}_{\mathrm{x}}$ and $\mathrm{Au}_{\text {Core }}-\mathrm{Au}_{1-\mathrm{x}} \mathrm{Pd}_{\mathrm{x}}$.Shell NPs and lacey carbon films for the $\mathrm{Au}-\mathrm{Pd}$ on $\mathrm{TiO}_{2}$ powders.

\subsubsection{X-ray Photoelectron Spectroscopy}

X-ray photoelectron spectroscopy (XPS) was carried out on a Physical Electronics VersaProbe III (East Chanhassen, MN, USA) with a monochromated $\mathrm{Al} \mathrm{K \alpha}$ source with a $100 \mu \mathrm{m}$ diameter $25 \mathrm{~W}$ beam, $55 \mathrm{eV}$ pass energy, and a take-off angle of $45^{\circ}$. Surface charging was neutralized by a low-voltage Ar-ion beam and a barium oxide neutralizer. Spectra were energetically corrected to a $284.8 \mathrm{eV} \mathrm{C} 1 \mathrm{~s}$ line and baseline corrected to a Shirley model. Peak fitting was performed with Physical Electronics' MultiPak software v9.6.0.15. Samples were prepared by drop-casting $5 \mu \mathrm{L}$ of $\mathrm{NP}-$ solvent solution onto glass substrates.

\subsubsection{Numerical Computation}

Electric near-field enhancements and SPR properties were studied and quantified using the discrete dipole approximation (DDA) package DDSCAT v7.3 by Draine and Flatau [37-39]. DDA uses Maxwell's equations to quantify absorption and scattering of an electric plane wave incident upon a subwavelength NP, discretized into a threedimensional ensemble of point dipoles susceptible to electric polarization according to their specified dielectric response $[6,28,29,40]$. Nanoparticle targets were generated using a custom MATLAB (v9.2, MathWorks, Natick, MA, USA) script based on Reference [29] according to the TEM-measured mean dimensions, with a $10 \mathrm{~nm}$ diameter $\mathrm{Au}_{1-\mathrm{x}} \mathrm{Pd}_{\mathrm{x}} \mathrm{NP}$ and $24 \mathrm{~nm} \mathrm{Au} \mathrm{Core}_{\mathrm{C}}-\mathrm{Au}_{1-\mathrm{x}} \mathrm{Pd}_{\mathrm{x}}$.Shell $\mathrm{NP}$ in the presence and absence of contacting anatase $\mathrm{TiO}_{2}(25 \mathrm{~nm}$ diameter $)$ in water $(\mathrm{n}=1.33)$. The inter-dipole spacing was $0.5 \mathrm{~nm}$. The DDA models presented herein consider only the anatase phase of $\mathrm{TiO}_{2}$ owing to both the anatase and rutile phases of $\mathrm{TiO}_{2}$ exhibiting a nearly identical dispersive dielectric behavior in the sub-band gap visible spectrum [6]. Therefore, under sub-band gap visible-light 
irradiation, the anatase and rutile forms are optically equivalent as they both screen the plasmon resonance.

\subsubsection{Photocatalytic Measurements}

Gas chromatography-mass spectrometry-multiple headspace extraction (GC-MSMHE) was performed on an Agilent Technologies 5975C Series GC/MSD, with Triple-Axis HED-EM Detector coupled to an Agilent 7697A Headspace Sampler utilized to perform headspace analysis of the photo-oxidation experiments. Sample vials were equilibrated at $60{ }^{\circ} \mathrm{C}$ under dark conditions for 20 minutes, and the headspace was extracted for the dark/thermal background [6]. Catalyst supports were used in all photocatalytic experiments. Photocatalytic EOR measurements of 1 wt.\% Au-Pd cocatalysts loaded on $\mathrm{TiO}_{2}$ samples (5 mg total) were performed in $0.010 \mathrm{M} \mathrm{HClO}_{4}+0.50 \mathrm{M}$ EtOH. NP suspensions were irradiated in purged GC-MS-MHE glass vials excited with solar-simulated light (i.e., denoted AM1.5G) using a $300 \mathrm{~W}$ Xe arc-lamp. The power density for the AM1.5G experiments $(>350 \mathrm{~nm})$ was set to $100 \mathrm{~mW} \cdot \mathrm{cm}^{-2}$ (i.e., $® \sim 1$ Sun). Photoreactor cells were irradiated for 1-4 h under constant stirring, and gaseous products were detected postirradiation.

\subsubsection{Electrochemical Measurements}

Catalyst supports (i.e., $\mathrm{TiO}_{2}$ and $\mathrm{C}$ ) were used in all electrochemical experiments. Electrochemical rotating disk electrode (RDE) hydrodynamic measurements were performed in a three-electrode custom-made quartz cell on a Solartron potentiostat. The three electrodes utilized were an $\mathrm{Ag} / \mathrm{AgCl}$ reference electrode (4 $\mathrm{M} \mathrm{KCl}$ with $\mathrm{AgCl}$ solution), a $\mathrm{Pt}$ coil counter electrode $\left(4.7 \mathrm{~cm}^{2}\right)$, and the $\mathrm{Au}-\mathrm{Pd} \mathrm{NPs}$ on $\mathrm{TiO}_{2}$ and carbon support deposited on polished glassy carbon (i.e., $0.196 \mathrm{~cm}^{-2}$ ) as the working electrodes. All measurements were temperature-controlled at $25{ }^{\circ} \mathrm{C}$ with water circulated through the outer jacket of the quartz cell. Prior to electrochemical measurements, $\mathrm{N}_{2}$ was bubbled in solution for $30 \mathrm{~min}$ and then placed in the headspace to maintain the sparged solution. A sequential cycling method was used to measure the $\mathrm{Au}-\mathrm{Pd}$ working electrodes in $1 \mathrm{M} \mathrm{KOH}$ supporting electrolyte at 200,100,50, 20, and $5 \mathrm{mV} \cdot \mathrm{s}^{-1}$, with the addition of $0.50 \mathrm{M} \mathrm{EtOH}$ for the EOR measurements. For the 200, 100, and $50 \mathrm{mV} \cdot \mathrm{s}^{-1}$ scan rates, the working electrodes were cycled 25 times each, whereas for the 20 and $5 \mathrm{mV} \cdot \mathrm{s}^{-1}$ scan rates, the electrodes were cycled 10 and 3 times each, respectively, under rotating conditions ( $\omega=400 \mathrm{rpm})$ to achieve reproducible cyclic voltammograms (CV) [30]. Chronoamperometric (CA) measurements were obtained with an applied bias of $+0.72 \mathrm{~V}$ (vs. reversible hydrogen electrode (RHE)) for $2150 \mathrm{~s}$ under chopped light irradiation (250 s light on/light off). The RDEs were irradiated with solar-simulated light (i.e., AM1.5G filter).

\section{Results and Discussion}

\subsection{Synthesis and Characterization of $A u-P d$ Bimetallic NPs}

Gold-palladium bimetallic nanoparticles $\left(\mathrm{Au}_{1-x} \mathrm{Pd}_{x}\right.$ and $\mathrm{Au}_{\mathrm{Cor}}-\mathrm{Au}_{1-x} \mathrm{Pd}_{x} \cdot$ Shell NPs) were prepared using stock solutions of $\mathrm{Au}$ and $\mathrm{Pd}$ chloride precursor salts in a modified colloidal synthetic method with systematic variation of the composition. Hightemperature $\left(100^{\circ} \mathrm{C}\right)$ growth conditions were used in the preparation of $\mathrm{Au}_{1-x} \mathrm{Pd}_{\mathrm{x}} \mathrm{NPs}$ to improve the nucleation and growth of homogeneous alloys. Alloyed $\mathrm{Au}_{1-x} \mathrm{Pd}_{\mathrm{x}} \mathrm{NPs}$ maintained their integrity after being coupled to the $3.2 \mathrm{eV}$ bandgap semiconductor $\mathrm{TiO}_{2}$ and were characterized by STEM-HAADF imaging [5] and EDXS elemental maps shown in Figure 1. Monodisperse spherical morphologies exhibited average particle diameters for $\mathrm{Au}(23.3 \pm 8.7 \mathrm{~nm}), \mathrm{Au}_{0.9} \mathrm{Pd}_{0.1}(7.3 \pm 5.9 \mathrm{~nm}), \mathrm{Au}_{0.75} \mathrm{Pd}_{0.25}(2.9 \pm 0.6 \mathrm{~nm}), \mathrm{Au}_{0.5} \mathrm{Pd}_{0.5}$ $(5.9 \pm 3.6 \mathrm{~nm}), \mathrm{Au}_{0.25} \mathrm{Pd}_{0.75}(7.6 \pm 4.5 \mathrm{~nm})$, and $\mathrm{Pd}(1.7 \pm 0.6 \mathrm{~nm})$ determined from statistical analysis of TEM images [5]. Elemental analysis of the NPs using STEM-EDXS spectra confirmed the average composition reflects the desired loading after subtracting $\mathrm{TiO}_{2}$ background, as shown in the Supplementary Figure S1. The Au-Pd distribution was synthetically controlled in a heterogeneous manner using core-shell growth techniques. 

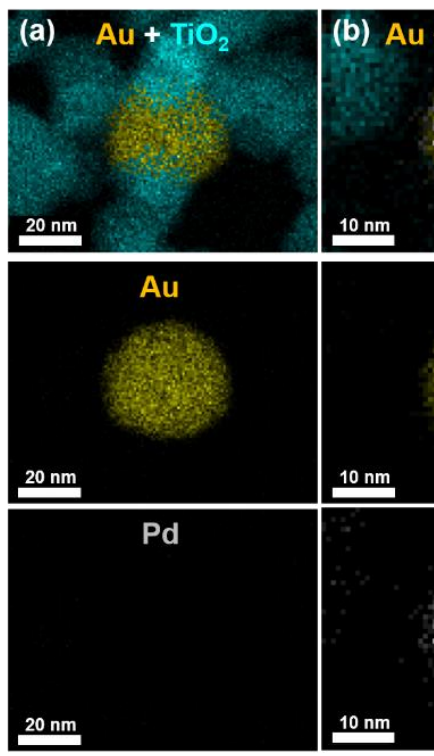

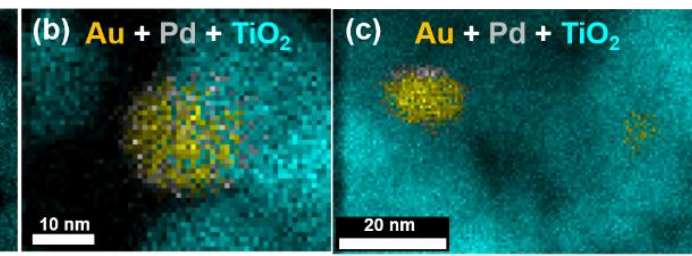

Au

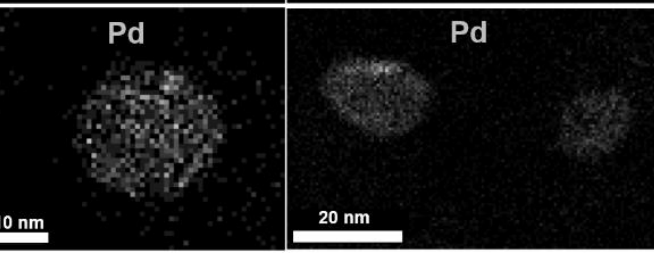

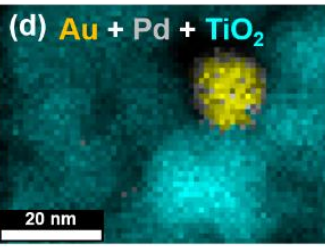
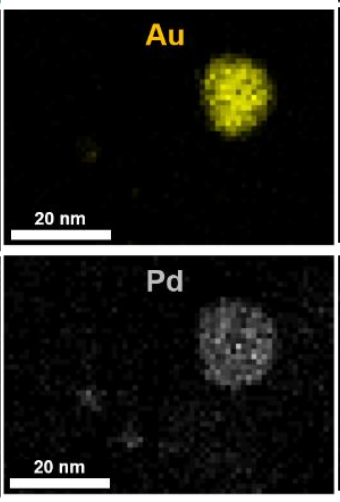
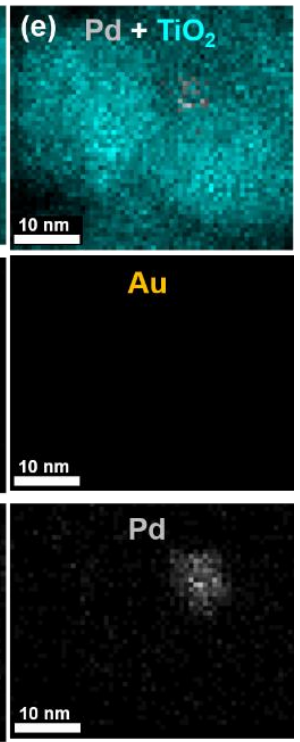

Figure 1. EDXS images taken in STEM mode representative of (a) $\mathrm{Au},(\mathbf{b}) \mathrm{Au}_{0.9} \mathrm{Pd}_{0.1}$, (c) $\mathrm{AuPd},(\mathbf{d}) \mathrm{Au}_{0.25} \mathrm{Pd}_{0.75}$, and $(\mathbf{e}) \mathrm{Pd}$ NPs on a $\mathrm{TiO}_{2}$ support, with the $\mathrm{Au}, \mathrm{Pd}$, and $\mathrm{TiO}_{2}$ shown in yellow, gray, and teal, respectively.

Heterogeneous core-shell NPs were grown at low-temperature conditions $\left(30{ }^{\circ} \mathrm{C}\right)$ in a two-step synthesis method: (1) growth of the Au NP core and (2) deposition of the desired $\mathrm{Au}_{1-\mathrm{x}} \mathrm{Pd}_{\mathrm{x}}$ shell. Shell thickness was varied by increasing the loading in the second synthesis step from 1 to $10 \mathrm{~mol} \%$ for a $\mathrm{Au}_{0.5} \mathrm{Pd}_{0.5}(\mathrm{AuPd})$ and $\mathrm{Pd}$ shell. The two-step core-shell synthesis method resulted in homogenous, faceted icosahedron Au core NPs with thin homogeneous shells that continued the growth pattern, as shown in Figure 2. Elemental mapping of Au and Pd via EDXS, shown in Figure 2, revealed a core-shell structure with 1-2 nm AuPd and Pd thick shells. Compositions of the core-shell NPs were confirmed by STEM-EDXS, shown in Supplementary Figure S2. XPS in Figure 3 and Supplementary Figure S3 confirmed the presence of metallic Au and Pd species for the alloy and core-shell NPs by the Au 4 f peaks at 83.7 and $87.4 \mathrm{eV}$ and the Pd 3d peaks at 335 and $340 \mathrm{eV}$ binding energies. Au exhibits convoluting $4 \mathrm{~d}$ peaks in the binding energy region of $\mathrm{Pd} 3 \mathrm{~d}$ as well but is suppressed with increasing Pd content. XPS analysis of the Au and Pd species for the $\mathrm{Au}_{0.9} \mathrm{Pd}_{0.1}$ alloy closely resembles both the $\mathrm{Au}_{\text {Core }} \mathrm{NPs}$ with $10 \% \mathrm{AuPd}$ and $10 \%$ Pd shell. XPS-measured valence band (VB) density-of-states (DOS) in Figure 3 and Supplementary Figure $S 4$ revealed a shift in $d$-band onset toward the $\mathrm{E}_{\mathrm{F}}$ (i.e., $0 \mathrm{eV}$ binding energy) and an increase in the DOS at the $\mathrm{E}_{\mathrm{F}}$ with an increase in Pd content, a signature of Pd observed in density functional theory (DFT) calculations and measurements of other Au-Pd bimetallics [30,35,40,41]. Modifying the position of the $d$-band center relative to the $\mathrm{E}_{\mathrm{F}}$ for $\mathrm{Au}-\mathrm{Pd}$ arises owing to the inherent properties of Pd. Additionally, mechanical strain and/or direct charge transfer between the two metals can take place in alloy and core-shell NPs; designated the ligand effect. The ligand effect can impact how molecules adsorb to the catalyst surface and subsequently modify the Au-Pd catalytic activity [18,42]. The $\mathrm{E}_{\mathrm{F}}$ of both $\mathrm{Au}$ and $\mathrm{Pd}$ lie lower in energy in relation to the conduction band (CB) minimum of $\mathrm{TiO}_{2}$, with the DOS increasing at the $\mathrm{E}_{\mathrm{F}}$ with an increase in the Pd content [43].

Compared to the alloyed $\mathrm{Au}_{1-x} \mathrm{Pd}_{\mathrm{x}} \mathrm{NPs}$, the $\mathrm{Au}_{\mathrm{Core}}-\mathrm{Au}_{1-x} \mathrm{Pd}_{x} \cdot$ Shell NPs exhibited facets with expanded average particle diameters due to secondary AuPd and Pd growth. Size distributions were determined from the statistical analysis of HAADF-STEM images and yielded average particle/shell diameters for the $\mathrm{Au}_{\text {Core }} \mathrm{NPs}$ with a $10 \mathrm{~mol} \% \mathrm{AuPd}_{\text {Shell }}$ (45.5 $\pm 13.9 \mathrm{~nm}$ overall diameter, $1.2 \pm 0.5 \mathrm{~nm}$ shell thickness) and $10 \mathrm{~mol} \% \mathrm{Pd}_{\text {Shell }}$ (30.5 $\pm 12.6 \mathrm{~nm}$ overall diameter, $1.3 \pm 0.6 \mathrm{~nm}$ shell thickness). Notably, tensile strain in the epitaxial thin shell enables the ligand effect to aid in modifying the $d$-band of the core-shell NP, which is absent for thicker shells (i.e., 7-9 nm) [18]. AuPd and Pd shell growth appeared to follow an epitaxial-like Frank-van der Merwe mode over the Aucore 
NP in Figure 2, and was consistent with related studies [26,29]. $\mathrm{Au}_{\text {Core }}-\mathrm{Au}_{1-x} \mathrm{Pd}_{x} \cdot \mathrm{Shell}_{\mathrm{NPs}}$ synthesized using the same procedure using < $10 \mathrm{~mol} \% \mathrm{Pd}$ yielded thinner $\mathrm{AuPd}$ and $\mathrm{Pd}$ shells with a lack of distinct crystal facets. Overall, chemical reductive deposition of thin AuPd and Pd shells onto Aucore NPs yielded an epitaxial interface for optimal Au-Pd optical characteristics to promote photocatalytic charge excitation and transfer.

UV-Vis spectroscopy was used to characterize the optical properties of the $\mathrm{Au}_{1-x} \mathrm{Pd}_{x}$ and $\mathrm{Au}_{\text {Core }}-\mathrm{Au}_{1-x} \mathrm{Pd}_{x}$. Shell NPs in solution, shown in Figure 4 and Supplementary Table S1, Figures S5 and S6. Pure Au NPs exhibited a $\lambda_{\text {Max }}$ of $526 \mathrm{~nm}$, but the relative intensity of the plasmonic resonance rapidly decayed by $50 \%$ after incorporating $10 \% \mathrm{Pd}$. Au is responsible for the plasmonic response at visible wavelengths, while Pd does not support visible SPR [18]. Pd exhibits a $d$-band center closer to the $\mathrm{E}_{\mathrm{F}}$, causing the optical response to be dominated by interband transitions and dampen the localized SPR at all frequencies, making it spectrally broad and lower in intensity $[18,28]$. Therefore, the rapid dampening of the SPR with increasing Pd observed for the alloys in Figure $4 \mathrm{a}$ is indicative of the homogeneous mixing of Pd into Au. In contrast, the core-shell morphologies in Figure $4 \mathrm{~b}$ retain a strong plasmonic response $\left(\lambda_{\text {Max }}\right)$ at $530 \mathrm{~nm}$, with linewidth expansion of the SPR peak $\left(\lambda_{\text {Max }}\right)$ owing to the Pd-containing shell layers. Spectral broadening observed at longer wavelengths $(>650 \mathrm{~nm})$ is attributed to $\mathrm{Pd}$ in the alloyed and core-shell compositions. Observable changes in the SPR were ostensibly due to the emergence of additional plasmon damping pathway(s) for the $\mathrm{Au}_{1-x} \mathrm{Pd}_{\mathrm{x}}$ and $\mathrm{Au}_{\text {Core }}-\mathrm{Au}_{1-x} \mathrm{Pd}_{x} \cdot$ Shell NPs $[36,44,45]$.

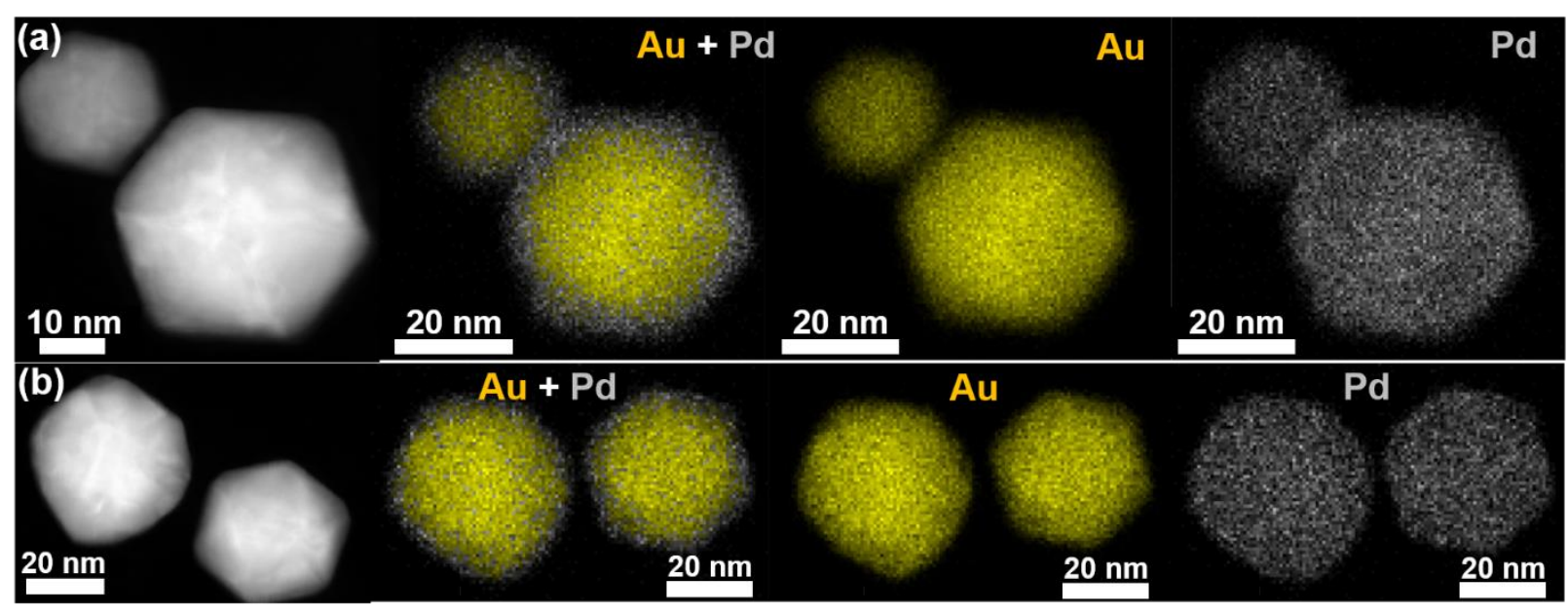

Figure 2. STEM-HAADF images and correlated EDXS maps of $\mathrm{Au}_{\text {Core }}$ NPs with (a) $10 \% \mathrm{AuPd}$ Shell and (b) $10 \%$ Pd $\mathrm{d}_{\text {Shell }}$, with the $\mathrm{Au}$ and $\mathrm{Pd}$ shown in yellow and gray, respectively.

Optical properties of $\mathrm{Au}_{1-x} \mathrm{Pd}_{\mathrm{x}}$ alloy and $\mathrm{Au}_{\text {Core }}-\mathrm{Au}_{1-x} \mathrm{Pd}_{x} \cdot$ Shell NPs coupled to the $3.2 \mathrm{eV}$ bandgap semiconductor $\mathrm{TiO}_{2}$ were characterized by UV-Vis diffuse reflectance spectra (DRS), shown in Figure 4c,d and Supplementary Figure S7. In Figure 4c,d, prepared powders exhibit a red-shifted SPR response compared to the alloys ( $\geq 50 \% \mathrm{Au}$ ) and coreshell NPs in solution by $\sim 20$ and $\sim 15-20 \mathrm{~nm}$, respectively. Interestingly, the plasmonic response was still present on $\mathrm{TiO}_{2}$ composites but appeared more prominent for the alloy NPs (i.e., $\geq 10 \% \mathrm{Pd}$ ) after coupling to $\mathrm{TiO}_{2}$, attributed to the dielectric screening interaction of $\mathrm{TiO}_{2}$ [6]. The $\lambda_{\mathrm{Max}}$ of the alloys on $\mathrm{TiO}_{2}$ blue-shifted with increasing Pd content, from $547 \mathrm{~nm}$ for $\mathrm{Au}$ to $450 \mathrm{~nm}$ for $\mathrm{Au}_{0.1} \mathrm{Pd}_{0.9}$. For the core-shell NPs, the $\lambda_{\mathrm{Max}}$ of $\mathrm{AuPd} \mathrm{d}_{\text {Shell }}$ red-shifted by $\sim 4 \mathrm{~nm}$ in comparison to the $\mathrm{Pd}_{\text {Shell }}$ owing to the $\mathrm{Au}$ in the shell.

DDA was used to model and quantify the plasmonic interactions of metal NPs in physical contact with $\mathrm{TiO}_{2}$ [6]. Local spatial distributions of the enhanced electric field intensity $\left(\left|\mathrm{E} / \mathrm{E}_{0}\right|^{2}\right)$ and far-field optical spectra of $\mathrm{Au}_{1-\mathrm{x}} \mathrm{Pd}_{\mathrm{x}}-\mathrm{TiO}_{2}$ and $\mathrm{Au}_{\mathrm{Core}}-\mathrm{Au}_{1-\mathrm{x}} \mathrm{Pd} \mathrm{d}_{\mathrm{x}} \cdot \mathrm{Shell}-\mathrm{TiO}_{2}$ heterodimers are shown in Figure 5, as well as Supplementary Table S1 and Figure S8. In each case, the strongest near-field enhancement magnitude is depicted at the heterodimers' calculated resonance wavelength for horizontal polarization (i.e., across $x$-axis). $A u_{1-x} P_{x}$ 
NPs were approximated as $10 \mathrm{~nm}, \mathrm{Au}_{\text {Core }}-\mathrm{Au}_{1-\mathrm{x}} \mathrm{Pd}_{\mathrm{x}} \cdot$ Shell $\mathrm{NPs}$ as $30 \mathrm{~nm} \mathrm{Au}_{\text {Core }}$ with 2 $\mathrm{nm}$ shells, and P25 as $25 \mathrm{~nm}$ in all cases. Composition was varied based on known dielectric functions for $\mathrm{Au}$ and $\mathrm{Pd}$, as well as that previously determined for AuPd [30]. In Figure 5a,b, pure Au NPs exhibited the strongest electric field enhancement followed by AuPd and Pd compositions, which exhibited similar intensities. Therefore, the electric field enhancement should not have a pronounced effect on the photocatalytic activity when comparing AuPd and Pd. However, the ligand effect and other SPR properties (hot-carrier injection and photothermal effects) of AuPd will significantly impact their catalytic activity for EOR compared to monometallic $\mathrm{Pd}$. Au-Pd nanomaterials and $\mathrm{TiO}_{2}$ exhibit energy localization at the plasmonic metal-semiconductor interfaces via dipole SPR excitations. DDA-simulated absorbance efficiency spectra of the Au-Pd NPs without $\mathrm{TiO}_{2}$ (Figure 5c) and with $\mathrm{TiO}_{2}$ (Figure $5 \mathrm{~d}$ ) were in good agreement with the experimentally determined SPR $\lambda_{\text {Max }}$ peak positions shown in Figure 4 and Supplementary Table S1. However, the predicted relative magnitudes for Pd-rich compositions were underestimated, especially with regards to alloy and core-shell NPs in contact with $\mathrm{TiO}_{2}$. Near-field maps and simulated absorbance spectra provide qualitative guides for interpreting measured optical influences at $\mathrm{AuPd}-\mathrm{TiO}_{2}$ interfaces for plasmonically driven photocatalytic reactions [6].
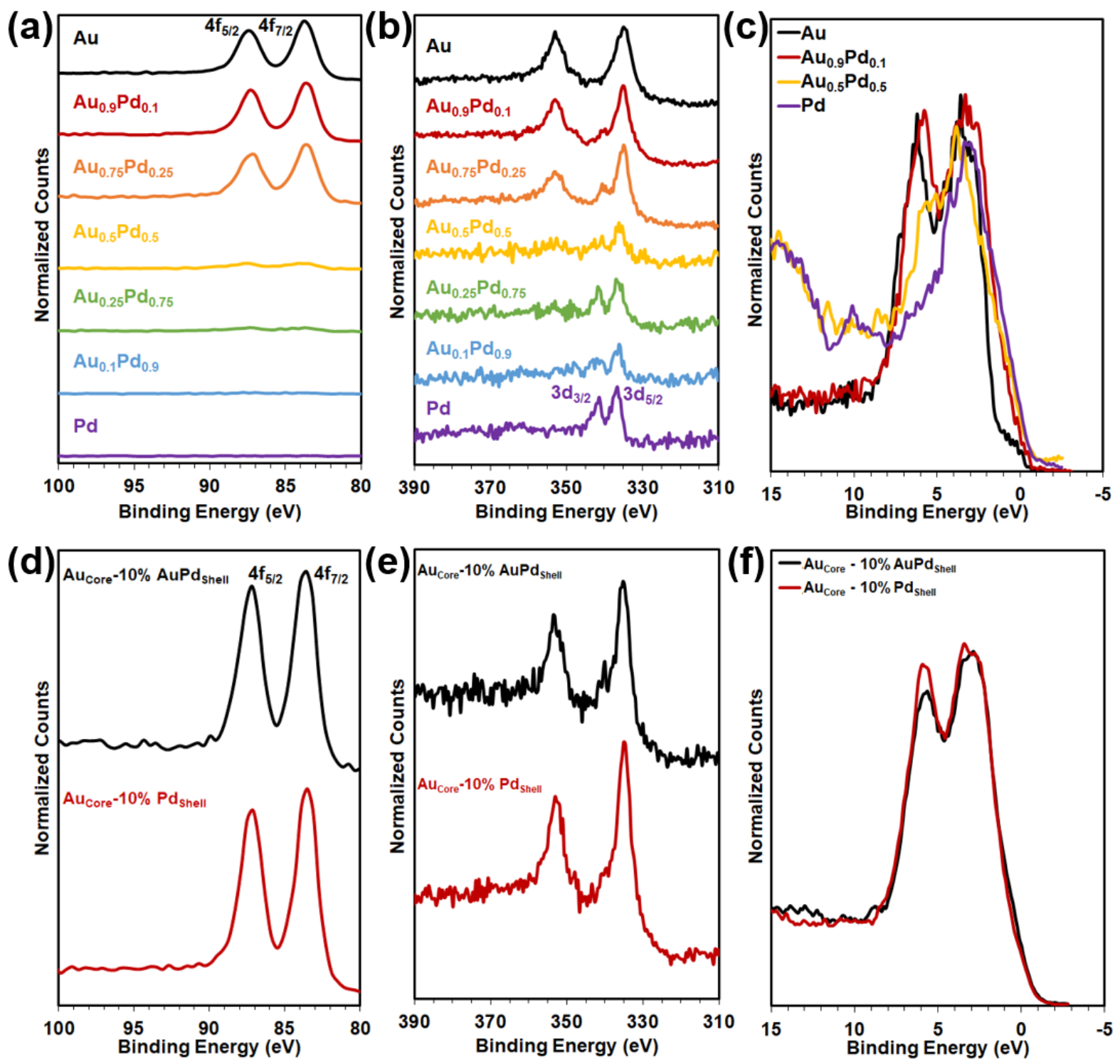

Figure 3. XPS analysis of the $(\mathbf{a}-\mathbf{c}) \mathrm{Au}_{1-x} \mathrm{Pd}_{x}$ alloys and $(\mathbf{d}-\mathbf{f}) \mathrm{Au}_{\mathrm{Core}}-\mathrm{Au}_{1-x} \mathrm{Pd}_{x}$.Shell NPs for the (a,d) Au 4f, (b,e) Pd 3d, and $(\mathbf{c}, \mathbf{f})$ VB regions. 
(a)
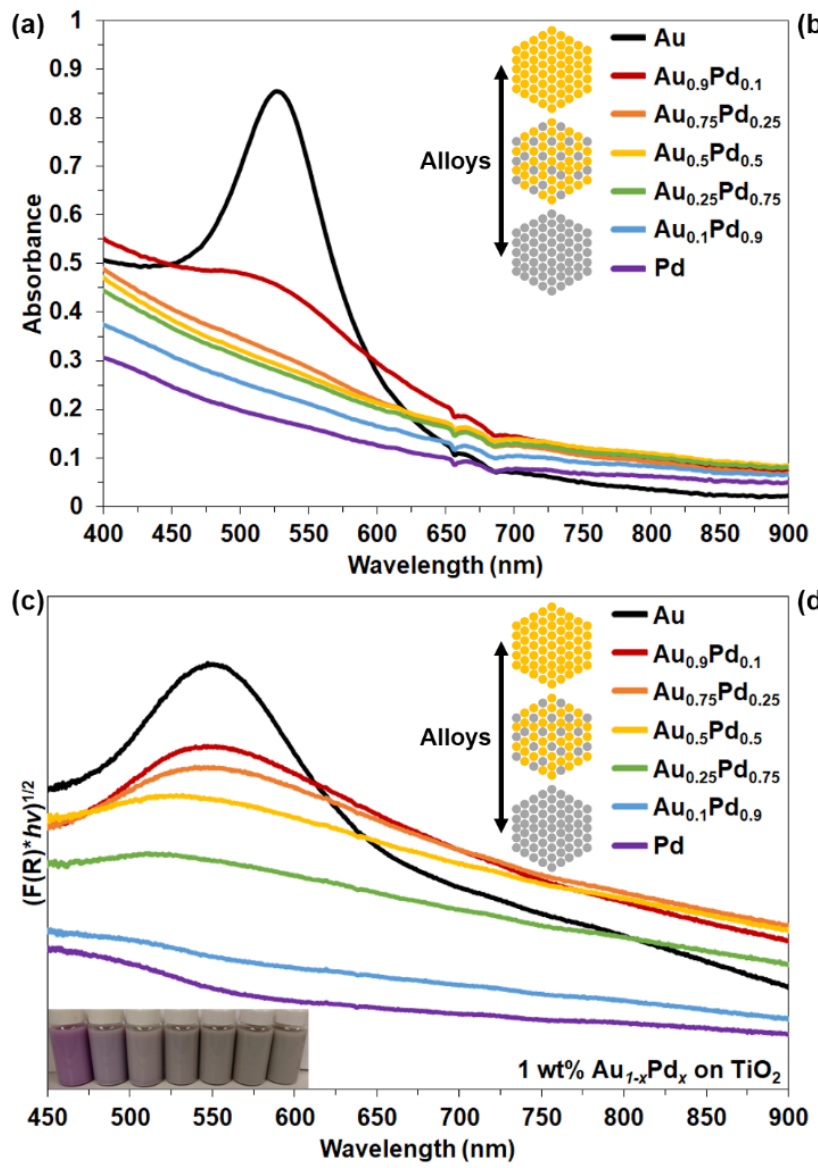
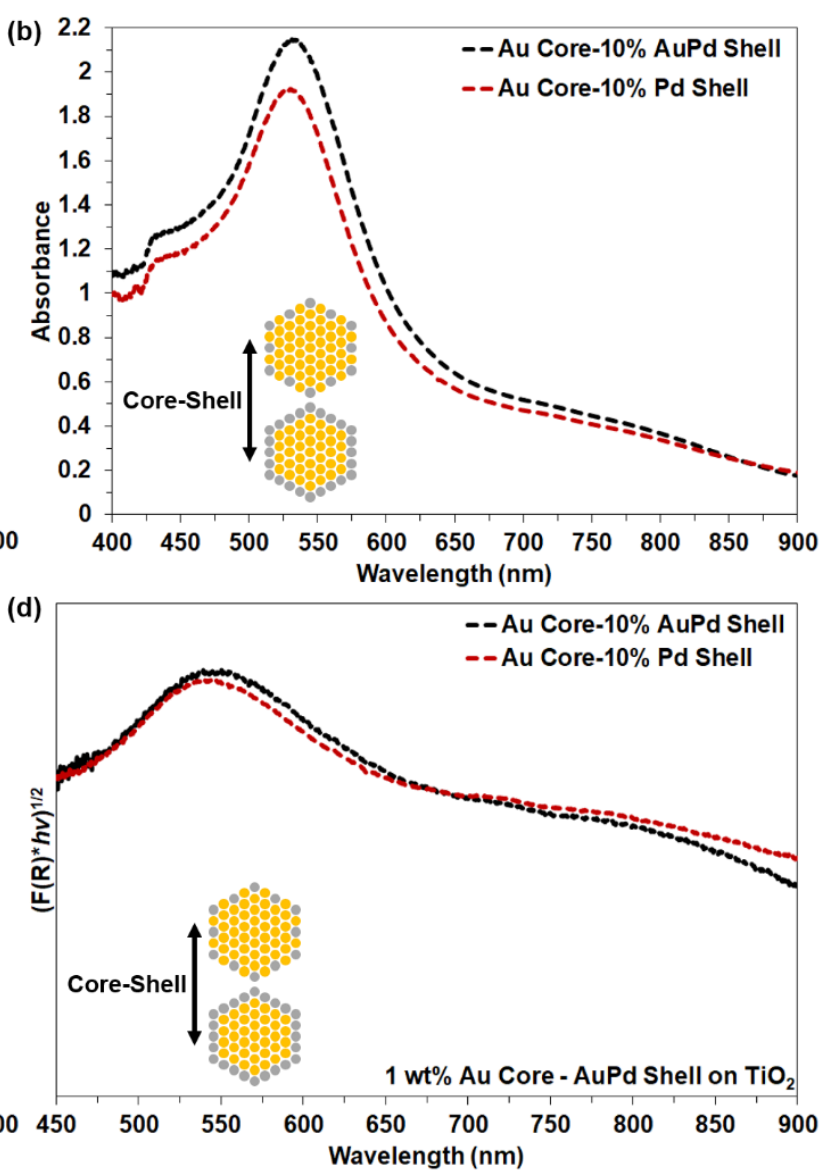

Figure 4. UV-Vis spectra of (a) $\mathrm{Au}_{1-x} \mathrm{Pd}_{x}$ and (b) $\mathrm{Au}_{\mathrm{Core}}-\mathrm{Au}_{1-x} \mathrm{Pd}$. Shell NPs in solution. UV-Vis DRS of 1 wt.\% (c) $\mathrm{Au}_{1-x} \mathrm{Pd}_{x} \mathrm{NPs}$ and (d) $\mathrm{Au}_{\text {Core }} \mathrm{NPs}$ with $10 \% \mathrm{Au}_{0.5} \mathrm{Pd}_{0.5} \cdot$ Shell and $10 \%$ Pd.Shell on $\mathrm{TiO}_{2}$ supports, with inset image of $\mathrm{Au}_{1-x} \mathrm{Pd}_{x}$ alloy NPs on $\mathrm{TiO}_{2}$ in a slurry mixture.

\subsection{Photocatalytic Ethanol Oxidation via $\mathrm{Au}-\mathrm{Pd} \mathrm{NPs}$ on $\mathrm{TiO}_{2}$ Supports}

Suspended particle photocatalysis of metal-oxide semiconductors is initiated by the absorption of photons to induce charge separation and diffusion of the photogenerated carriers to surface active sites to react with adsorbed chemical species $[3,5,6,46]$. Metaloxide $\mathrm{TiO}_{2}$ supports were photosensitized with homogeneously alloyed $\mathrm{Au}_{1-x} \mathrm{Pd}_{\mathrm{x}}$ and heterogeneous $\mathrm{Au}_{\text {Core }}-\mathrm{Au}_{1-x} \mathrm{Pd}_{x}$. Shell NPs to be used as hybrid photoreactors for $\mathrm{EtOH}$ photo-oxidation. Plasmon-mediated photocatalytic EOR performance measurements were conducted under solar-simulated (AM1.5G) irradiation for 1-4 h, while the gaseous oxidation products were measured using a GC-MS-MHE analysis method $[5,6]$. Thermal background measurements were collected under dark conditions for each sample by heating the photoreactor at $60^{\circ} \mathrm{C}$ to thermal equilibrium, which yielded negligible oxidation of EtOH. Plasmonically enhanced photocatalytic mass activities for $\mathrm{Au}_{1-x} \mathrm{Pd}_{x}$ and $\mathrm{Au}_{\mathrm{Core}^{-}}$ $\mathrm{Au}_{1-x} \mathrm{Pd}_{x} \cdot$ Shell NPs dispersed on $\mathrm{TiO}_{2}$ are shown in Figure 6, Table 1, and in Supplementary Tables S2 and S3 for the oxidation products of $\mathrm{EtOH}$ conversion, acetaldehyde $\left(\mathrm{CH}_{3} \mathrm{CHO}\right.$, $\left.n=2 \mathrm{e}^{-}\right)$and carbon dioxide $\left(\mathrm{CO}_{2}, n=12 \mathrm{e}^{-}\right)$. In Figure 6, the mass activity for $\mathrm{CO}_{2}$ is plotted on the left axis represented by purple $(1 \mathrm{~h})$ and blue $(4 \mathrm{~h})$ bars, while the mass activity for $\mathrm{CH}_{3} \mathrm{CHO}$ is plotted on the right axis represented by orange diamond $(1 \mathrm{~h})$ and green triangle $(4 \mathrm{~h})$ markers. 

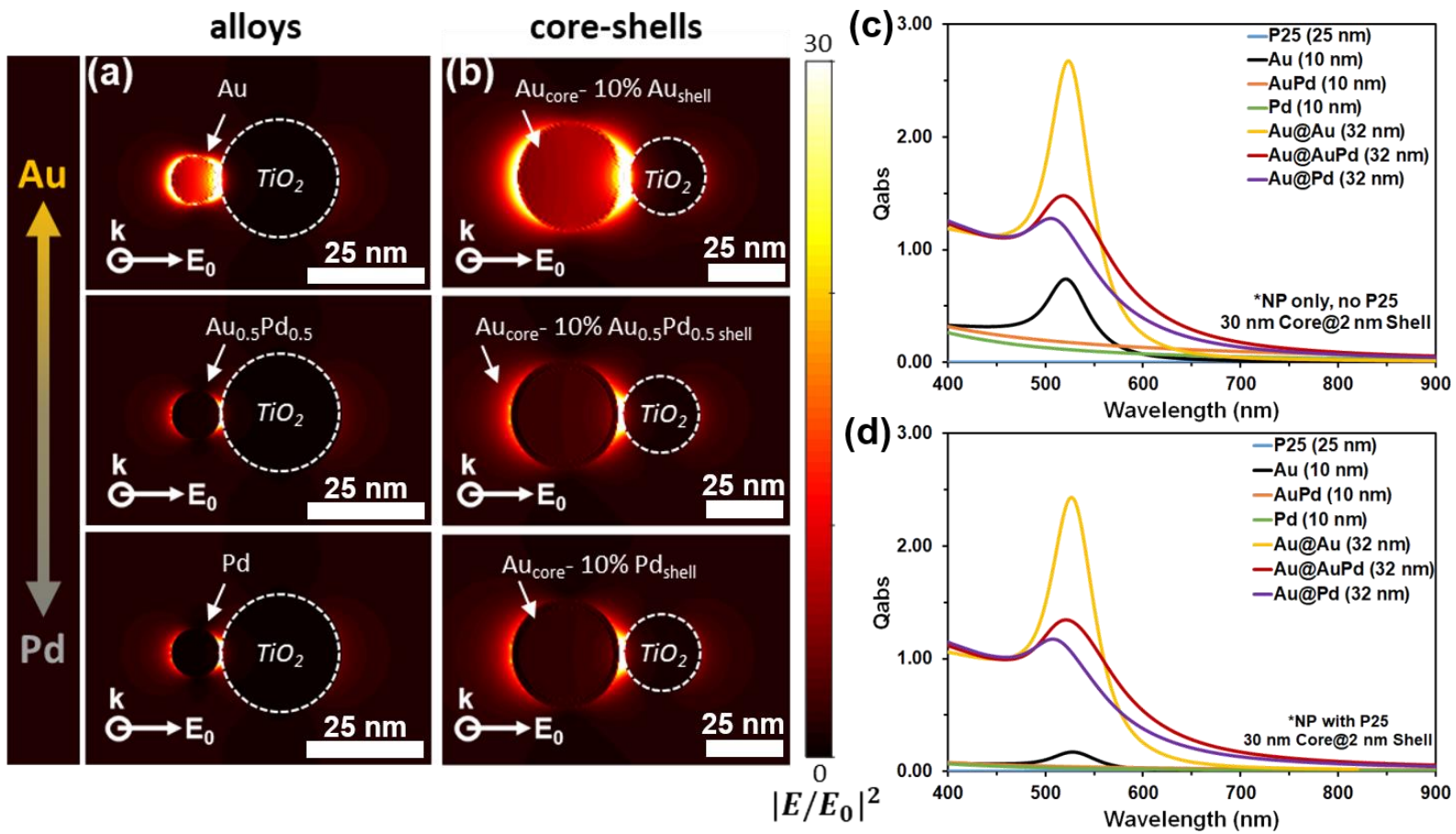

Figure 5. DDA simulations of the spatial distributions of the electric field enhancement $\left(\left|\mathrm{E} / \mathrm{E}_{0}\right|^{2}\right)$ for spherical $(\mathbf{a}) \mathrm{Au}_{1-x} \mathrm{Pd}_{x}$ and (b) $\mathrm{Au}_{\mathrm{Core}}-\mathrm{Au}_{1-x} \mathrm{Pd}_{x}$. Shell $\mathrm{NPs}$ in contact with a spherical $\mathrm{TiO}_{2} \mathrm{NP}$ under resonance wavelength excitation. Wave vector is incident into the image. DDA simulated absorption efficiency $\left(\mathrm{Q}_{\mathrm{abs}}\right)$ spectra for $(\mathbf{c}) \mathrm{Au}-\mathrm{Pd} \mathrm{NPs}$ only and (d) Au-Pd NPs in contact with $\mathrm{TiO}_{2}$.

In Figure 6a and Table 1, all of the investigated elemental compositions for the $\mathrm{Au}_{1-x} \mathrm{Pd}_{x}$ alloys (outlined in black) and $\mathrm{Au}_{\text {Core }}-\mathrm{Au}_{1-x} \mathrm{Pd}_{x} \cdot$ Shell (outlined in red) NPs on $\mathrm{TiO}_{2}$ were irradiated for $1 \mathrm{~h}$ under $\mathrm{AM} 1.5 \mathrm{G}$ and the primary photocatalytic products detected by GC-MS-MHE were $\mathrm{CO}_{2}$ (purple bars) and $\mathrm{CH}_{3} \mathrm{CHO}$ (orange diamonds). The activity for $\mathrm{TiO}_{2}$ without a cocatalyst was $87.11 \mu \mathrm{mol} \mathrm{CO} / \mathrm{g}$ and $0.60 \mu \mathrm{mol} \mathrm{CH} \mathrm{CH}_{3} \mathrm{CHO} / \mathrm{g}$, as listed in Supplementary Table S2. Mass activity of the $\mathrm{Au}_{1-x} \mathrm{Pd}_{x}$ alloys increased with an increase in the Pd content ( $x=0$ to $x=0.5)$ from $132.32 \mu \mathrm{mol} \mathrm{CO}_{2} / \mathrm{g}$ and $0.26 \mu \mathrm{mol}$ $\mathrm{CH}_{3} \mathrm{CHO} / \mathrm{g}$ for $\mathrm{Au}$ to $221.67 \mu \mathrm{mol} \mathrm{CO} 2 / \mathrm{g}$ and $0.96 \mu \mathrm{mol} \mathrm{CH}_{3} \mathrm{CHO} / \mathrm{g}$ for AuPd. However, the mass activity did not significantly increase after increasing the Pd content from $x=0.5$

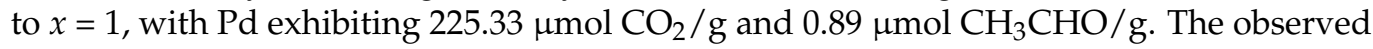
plateau in mass activity for $>50 \%$ Pd can be attributed to a loss in the SPR absorption at low $\mathrm{Au}$ content. The $\mathrm{Au}_{\mathrm{Core}}-10 \% \mathrm{AuPd}$.Shell $\mathrm{NPs}$ on $\mathrm{TiO}_{2}$ exhibited mass activities of $164.99 \mu \mathrm{mol} \mathrm{CO} 2 / \mathrm{g}$ and $0.36 \mu \mathrm{mol} \mathrm{CH}_{3} \mathrm{CHO} / \mathrm{g}$, which was between that of the alloy compositions of $\mathrm{Au}_{0.9} \mathrm{Pd}_{0.1}(147.09 \mu \mathrm{mol} \mathrm{CO} / \mathrm{g})$ and $\mathrm{Au}_{0.75} \mathrm{Pd}_{0.25}(176.76 \mu \mathrm{mol} \mathrm{CO} 2 / \mathrm{g})$. In contrast, the $\mathrm{Au}_{\mathrm{Core}}-10 \% \mathrm{Pd}$.Shell NPs exhibited the highest mass activity of all samples with $283.28 \mu \mathrm{mol} \mathrm{CO} 2 / \mathrm{g}$ and $1.06 \mu \mathrm{mol} \mathrm{CH} \mathrm{CH}_{3} \mathrm{CHO} / \mathrm{g}$. The Au core maintains SPR absorption with a thin Pd shell at the surface to enhance catalytic EOR. Coupling plasmonic $\mathrm{Au}$ to $\mathrm{TiO}_{2}$ improves the chemical energy conversion reactions via plasmon-mediated hot electron transfer (PMET) - injection of hot electrons into the CB of a semiconductor. Detailed spectroscopic studies by Tan et al. have proposed the mechanism for photoenhancement due to PMET charge transfer between $\mathrm{Au}$ and $\mathrm{TiO}_{2}$ for EOR: (1) activation of oxygen at oxygen vacancies on $\mathrm{TiO}_{2}$, (2) dehydrogenation of $\mathrm{EtOH}$ to form acetaldehyde, (3) cleaving of $\mathrm{C}-\mathrm{C}$ bond, (4) further oxidation to form $\mathrm{CO}_{2}$, and (5) electron transfer from $\mathrm{Au}$ to $\mathrm{TiO}_{2}$ [11,12]. PMET enables $\mathrm{Au}$ to accumulate hot holes and stabilize the $\mathrm{Pd}$ as a cocatalyst; facilitating the $\mathrm{Au}-\mathrm{Pd} \mathrm{NPs}$ to act as the primary active site for EOR [3,6]. Plasmon-induced heating (photothermal) provides the means to overcome the thermal barrier necessary to selectively cleave the $\mathrm{C}-\mathrm{C}$ bond and hinder the poisoning effects on Pd [5,6,9]. Addition of $\mathrm{Au}-\mathrm{Pd}$ 
cocatalysts with either an alloy or core-shell nanostructure resulted in an increase in the $\mathrm{CO}_{2}$ mass activity, i.e., the complete conversion of EtOH.
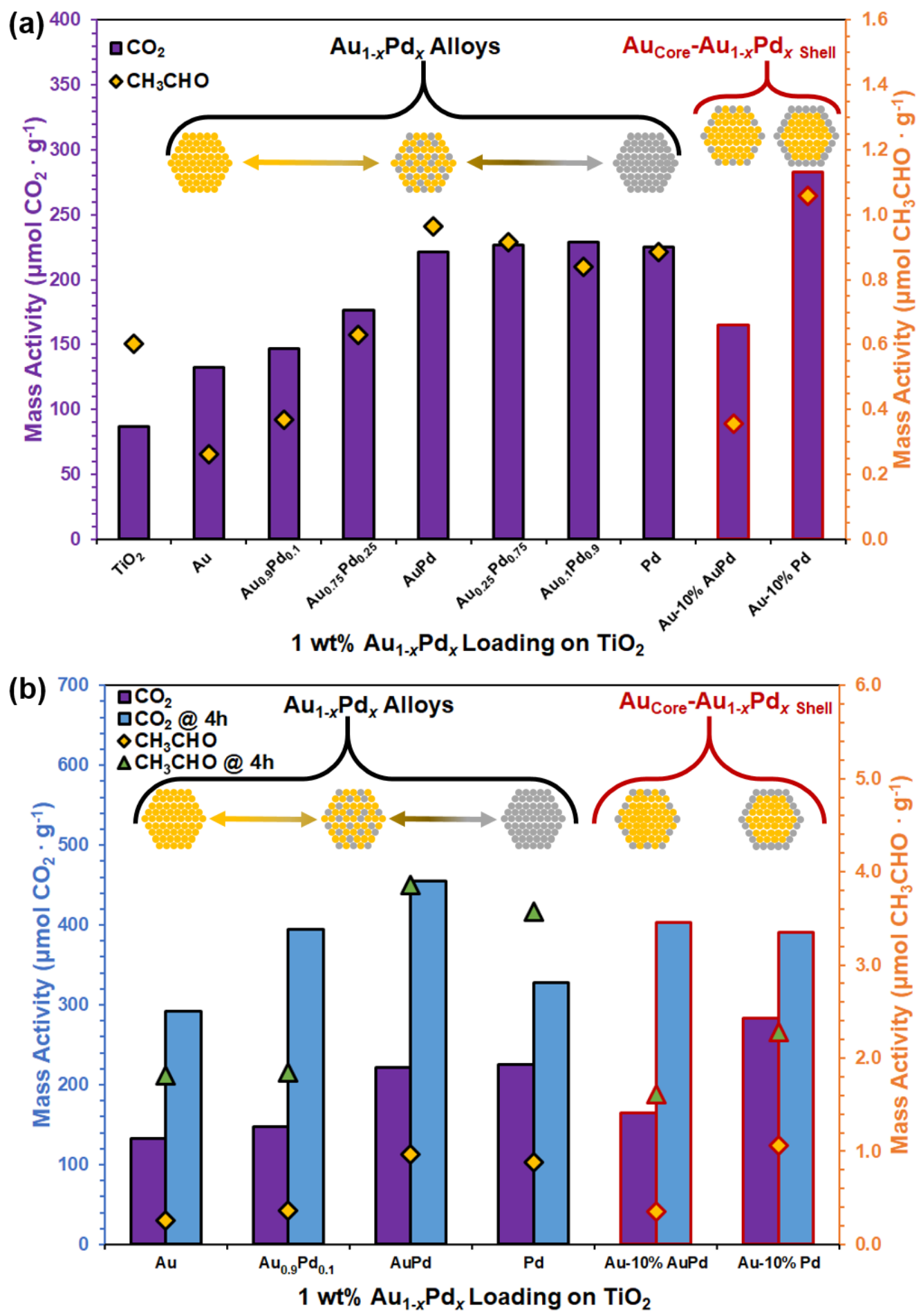

Figure 6. Plasmonically enhanced photo-oxidation of EtOH to $\mathrm{CO}_{2}$ and/or $\mathrm{CH}_{3} \mathrm{CHO}$ intermediary for $1 \mathrm{~h}$ duration for $\mathrm{Au}_{1-x} \mathrm{Pd}_{x}$ alloy (outlined in black) and $\mathrm{Au}_{\mathrm{Core}}-\mathrm{Au}_{1-x} \mathrm{Pd}_{x} \cdot$ Shell (outlined in red) NPs on $\mathrm{TiO}_{2}$ under (a) AM1.5G irradiation for all compositions and (b) 1-4 h AM1.5G irradiation for select compositions. Note: $\mathrm{CO}_{2}$ is plotted on the left axis represented by purple $(1 \mathrm{~h})$ and blue $(4 \mathrm{~h})$ bars, while $\mathrm{CH}_{3} \mathrm{CHO}$ is plotted on the right axis represented by orange diamond $(1 \mathrm{~h})$ and green triangle $(4 \mathrm{~h})$ markers. 
Table 1. Mass activity of 1 wt. $\% \mathrm{Au}_{1-x} \mathrm{Pd}_{x}$ and $\mathrm{Au}_{\mathrm{Core}}-\mathrm{Au}_{1-x} \mathrm{Pd} \mathrm{d}_{x} \cdot$ Shell $\mathrm{NPs}$ on $\mathrm{TiO}_{2}$ supports under AM1.5G irradiation for $1 \mathrm{~h}$ determined from GC-MS-MHE analysis.

\begin{tabular}{|c|c|c|}
\hline Sample & $\mu \mathrm{mol} \mathrm{CO} 2 / \mathrm{g}$ & $\mu \mathrm{mol} \mathrm{CH}{ }_{3} \mathrm{CHO} / \mathrm{g}$ \\
\hline $\mathrm{TiO}_{2}$ & 87.11 & 0.60 \\
\hline $\mathrm{Au}$ & 132.32 & 0.26 \\
\hline $\mathrm{Au}_{0.9} \mathrm{Pd}_{0.1}$ & 147.09 & 0.37 \\
\hline $\mathrm{Au}_{0.75} \mathrm{Pd}_{0.25}$ & 176.76 & 0.63 \\
\hline $\mathrm{Au}_{0.5} \mathrm{Pd}_{0.5}$ & 221.67 & 0.96 \\
\hline $\mathrm{Au}_{0.25} \mathrm{Pd}_{0.75}$ & 226.43 & 0.92 \\
\hline $\mathrm{Au}_{0.1} \mathrm{Pd}_{0.9}$ & 228.62 & 0.84 \\
\hline $\mathrm{Pd}$ & 225.33 & 0.89 \\
\hline $\mathrm{Au}-10 \% \mathrm{AuPd}$ & 164.99 & 0.36 \\
\hline Au-10\% Pd & 283.28 & 1.06 \\
\hline
\end{tabular}

In Figure $6 \mathrm{~b}, \mathrm{Au}, \mathrm{Au}_{0.9} \mathrm{Pd}_{0.1}, \mathrm{AuPd}, \mathrm{Pd}, \mathrm{Au}_{\mathrm{Core}}-10 \% \mathrm{AuPd}$.Shell, and $\mathrm{Au}_{\mathrm{Core}}-10 \%$ $\mathrm{Pd}$.shell $\mathrm{NPs}$ on $\mathrm{TiO}_{2}$ were further investigated as photocatalysts by comparing product yields under prolonged $(4 \mathrm{~h})$ irradiation, listed in Table 2 and Supplementary Table S3. After $4 \mathrm{~h}$ irradiation, the yield of $\mathrm{CO}_{2}$ (blue bars) and $\mathrm{CH}_{3} \mathrm{CHO}$ (green triangles) increased for all compositions in comparison to the yields collected after $1 \mathrm{~h}$ irradiation $\left(\mathrm{CO}_{2}\right.$, purple bars; $\mathrm{CH}_{3} \mathrm{CHO}$, orange diamonds). Pd had the lowest EOR activity for complete EtOH conversion of the Pd-containing cocatalysts $(328 \mu \mathrm{mol} \mathrm{CO} 2 / \mathrm{g})$. Initial rate of conversion for Pd diminished by $64 \%$ to $82 \mu \mathrm{mol} \mathrm{CO} \mathrm{CO}_{2} \cdot \mathrm{g}^{-1} \cdot \mathrm{h}^{-1}$ after $4 \mathrm{~h}$ irradiation owing to binding of intermediates to its surface active sites $[5,25,30]$. Plasmonic Au cocatalysts exhibited the lowest overall activity of the cocatalysts after prolonged irradiation $\left(292 \mathrm{CO}_{2} / \mathrm{g}\right)$, with its initial rate of conversion diminished by $45 \%$ to $73.09 \mu \mathrm{mol} \mathrm{CO} 2 \cdot \mathrm{g}^{-1} \cdot \mathrm{h}^{-1}$. Notably, the product yields for $\mathrm{Au}_{1-x} \mathrm{Pd}_{x}$ alloy and $\mathrm{Au}_{\text {Core }}-\mathrm{Au}_{1-x} \mathrm{Pd}_{x}$.Shell compositions that contained 5-10 mol\% Pd (i.e., $\mathrm{Au}_{0.9} \mathrm{Pd}_{0.1}, \mathrm{Au}-10 \% \mathrm{AuPd}$, and $\mathrm{Au}-10 \% \mathrm{Pd}$ ) were relatively similar with regard to complete $\mathrm{EtOH}$ conversion (391-403 $\mathrm{CO}_{2} / \mathrm{g}$ ). The rate of complete $\mathrm{EtOH}$ conversion $\left(97.68-100.78 \mu \mathrm{mol} \mathrm{CO} 2 \cdot \mathrm{g}^{-1} \cdot \mathrm{h}^{-1}\right)$ indicated similar reactivity and stability for alloy and core-shell NPs after prolonged irradiation. Therefore, nanostructuring (alloy vs. core-shell) at low Pd content $(\leq 10 \% \mathrm{Pd})$ did not have a pronounced effect on the mass activity for long duration photocatalytic measurements. AuPd (1:1 mole ratio) alloy on $\mathrm{TiO}_{2}$ was the most active for complete $\mathrm{EtOH}$ conversion after prolonged AM1.5G irradiation $(456 \mu \mathrm{mol} \mathrm{CO} / \mathrm{g})$ and retained $67 \%$ of its initial rate of conversion $\left(113.92 \mu \mathrm{mol} \mathrm{CO} 2 \cdot \mathrm{g}^{-1} \cdot \mathrm{h}^{-1}\right)$. Alloyed NPs can exhibit plasmonic, catalytic, and ligand effects observed in core-shell NPs, with the addition of the atomically distributed surface active sites to inhibit side reactions and poisoning [18,30,47]. The AuPd alloy exhibited SPR absorption and contained a sufficient amount of Pd metal to significantly improve its reactant chemisorption and subsequent EOR activity. Catalytic Pd enabled the retention and utilization of photogenerated carriers generated in Au for photocatalytic EOR.

Table 2. Mass activities of $1 \mathrm{wt} . \% \mathrm{Au}_{1-x} \mathrm{Pd}_{x}$ and $\mathrm{Au}_{\mathrm{Core}}-\mathrm{Au}_{1-x} \mathrm{Pd} \cdot$.Shell $\mathrm{NPs}$ for select compositions on $\mathrm{TiO}_{2}$ supports under AM1.5G for $4 \mathrm{~h}$, determined from GC-MS-MHE analysis.

\begin{tabular}{|c|c|c|c|c|}
\hline Sample & Total $\mu \mathrm{mol} \mathrm{CO} \mathrm{CO}_{2} / \mathrm{g}$ & Total $\mu \mathrm{mol} \mathrm{CH}_{3} \mathrm{CHO} / \mathrm{g}$ & $\begin{array}{c}\text { Total Rate } \\
\left(\mu \mathrm{mol} \mathrm{CO} \mathrm{CO}_{2} \cdot \mathrm{g}^{-1} \cdot \mathrm{h}^{-1}\right)\end{array}$ & $\begin{array}{c}\text { Total Rate } \\
\left(\mu \mathrm{mol} \mathrm{CH}{ }_{3} \mathrm{CHO} \cdot \mathrm{g}^{-1} \cdot \mathrm{h}^{-1}\right)\end{array}$ \\
\hline $\mathrm{Au}$ & 292.35 & 1.82 & 73.09 & 0.45 \\
\hline $\mathrm{Au}_{0.9} \mathrm{Pd}_{0.1}$ & 394.63 & 1.84 & 98.66 & 0.46 \\
\hline $\mathrm{Au}_{0.5} \mathrm{Pd}_{0.5}$ & 455.67 & 3.86 & 113.92 & 0.96 \\
\hline $\mathrm{Pd}$ & 327.98 & 3.57 & 82.00 & 0.89 \\
\hline $\mathrm{Au}-10 \% \mathrm{AuPd}$ & 403.13 & 1.61 & 100.78 & 0.40 \\
\hline $\mathrm{Au}-10 \% \mathrm{Pd}$ & 390.72 & 2.28 & 97.68 & 0.57 \\
\hline
\end{tabular}




\subsection{Electrochemical Ethanol Oxidation via Au-Pd NPs on Carbon Supports}

Photocatalytically active $\mathrm{Au}_{1-x} \mathrm{Pd}_{x}$ alloys and $\mathrm{Au}_{\text {Core }}-\mathrm{Au}_{1-x} \mathrm{Pd}$-Shell NPs were selected for electrochemical measurement of their EOR performance. Figure 7 shows cyclic voltammetry $(\mathrm{CV})$ scans of $\mathrm{Au}_{1-x} \mathrm{Pd}_{x}$ and $\mathrm{Au}_{\mathrm{Core}}-\mathrm{Au}_{1-x} \mathrm{Pd}_{x}$.Shell NPs on conductive carbon supports on a rotating disk electrode (RDE) immersed in $0.5 \mathrm{M} \mathrm{EtOH}(1 \mathrm{M} \mathrm{KOH}$ supporting electrolyte, $25^{\circ} \mathrm{C}$ ) under dark conditions. Onset potentials were identified as the threshold voltage for appreciable positive current, which indicated the start of the electrochemically driven EOR. Onset potentials during the anodic forward scan (i.e., left to right; $\mathrm{V}_{\mathrm{F}}$ and $\mathrm{I}_{\mathrm{F}}$ ) were found to be reductively shifted from $+0.72 \mathrm{~V}$ for $\mathrm{Au}$ to $+0.30 \mathrm{~V}$ for Pd, listed in Table 3. Previous studies have reported $\sim 1.25$ to $5 \mathrm{~mA} / \mathrm{cm}^{2}$ for pure $\mathrm{Au}$ to Pd compositions, respectively $[48,49]$. Greater overpotential on $\mathrm{Au}$ is characteristic of EOR on Au compared with Pd for bulk metal surfaces [25,30,33]. The EOR current peaks for both samples during their anodic scan $\left(\mathrm{V}_{\mathrm{F}}\right.$ and $\left.\mathrm{I}_{\mathrm{F}}\right)$ were characteristically followed by a decrease in current owing to surface passivation of the active catalytic sites that were covered by EOR intermediate products [25,30,33]. Active sites were cleaned upon the reverse, cathodic scans (i.e., right to left; $V_{R}$ and $I_{R}$ ), which resulted in the positive-current takeoff to higher EOR peak current magnitude owing to the freshly renewed catalytic surface [30]. Supplementary Figure S9 compares CVs in the dark immersed in $1 \mathrm{M} \mathrm{KOH}$ supporting electrolyte without $0.5 \mathrm{M}$ EtOH. Peak anodic EOR current for the $\mathrm{Au}_{1-x} \mathrm{Pd}_{x}$ alloys increased from $1.51 \mathrm{~mA} \mathrm{~cm}^{-2}$ for $\mathrm{Au}, 9.26 \mathrm{~mA} \mathrm{~cm}^{-2}$ for $\mathrm{Au}_{0.9} \mathrm{Pd}_{0.1}, 29.14 \mathrm{~mA} \mathrm{~cm}{ }^{-2}$ for $\mathrm{AuPd}$, and to $30.80 \mathrm{~mA} \mathrm{~cm}^{-2}$ for Pd, with current densities comparable or better than previous studies [48-52]. AuPd alloy exhibited similar electrochemical EOR activity as pure Pd despite 50\% less Pd content. Increased EOR activity for the AuPd alloy is in part due to the superior catalytic performance inherent to $\mathrm{Pd}$, as well as the resistance to catalyst poisoning inherent to $\mathrm{Au}$. No significant changes in the onset potential or current density were observed for $>50 \% \mathrm{Pd}$ alloy composition. In contrast, peak anodic current densities of the core-shell NPs in Figure $7 \mathrm{~b}$ were lower and anodically shifted to higher onset potentials with $3.37 \mathrm{~mA} \mathrm{~cm}^{-2}$ at $0.82 \mathrm{~V}$ for $\mathrm{Au}_{\text {Core }}-\mathrm{AuPd}$.Shell and $1.55 \mathrm{~mA} \mathrm{~cm}{ }^{-2}$ at $0.94 \mathrm{~V}$ for $\mathrm{Au}_{\mathrm{Core}}-\mathrm{Pd}$.Shell. Secondary anodic peaks at higher potential were attributed to the $\mathrm{Au}$ signature for the $\mathrm{Au}_{0.9} \mathrm{Pd}_{0.1}$ alloy with $3.81 \mathrm{~mA} \mathrm{~cm}{ }^{-2}$ at $1.17 \mathrm{~V}$, $\mathrm{Au}_{\text {Core }}-\mathrm{AuPd}$. Shell with $1.60 \mathrm{~mA} \mathrm{~cm}^{-2}$ at $1.18 \mathrm{~V}$, and $\mathrm{Au}_{\mathrm{Core}}-\mathrm{Pd}$. Shell with $2.96 \mathrm{~mA} \mathrm{~cm}^{-2}$ at $1.21 \mathrm{~V}$. Under dark conditions, electrochemical properties were investigated for alloy and core-shell NPs on conductive carbon supports without SPR effects. Homogenous mixing of $\mathrm{Au}$ and $\mathrm{Pd}$ yielded optimal results, while heterogeneous core-shells separated the metals into defined regions, resulting in lower current densities at analogous compositions.
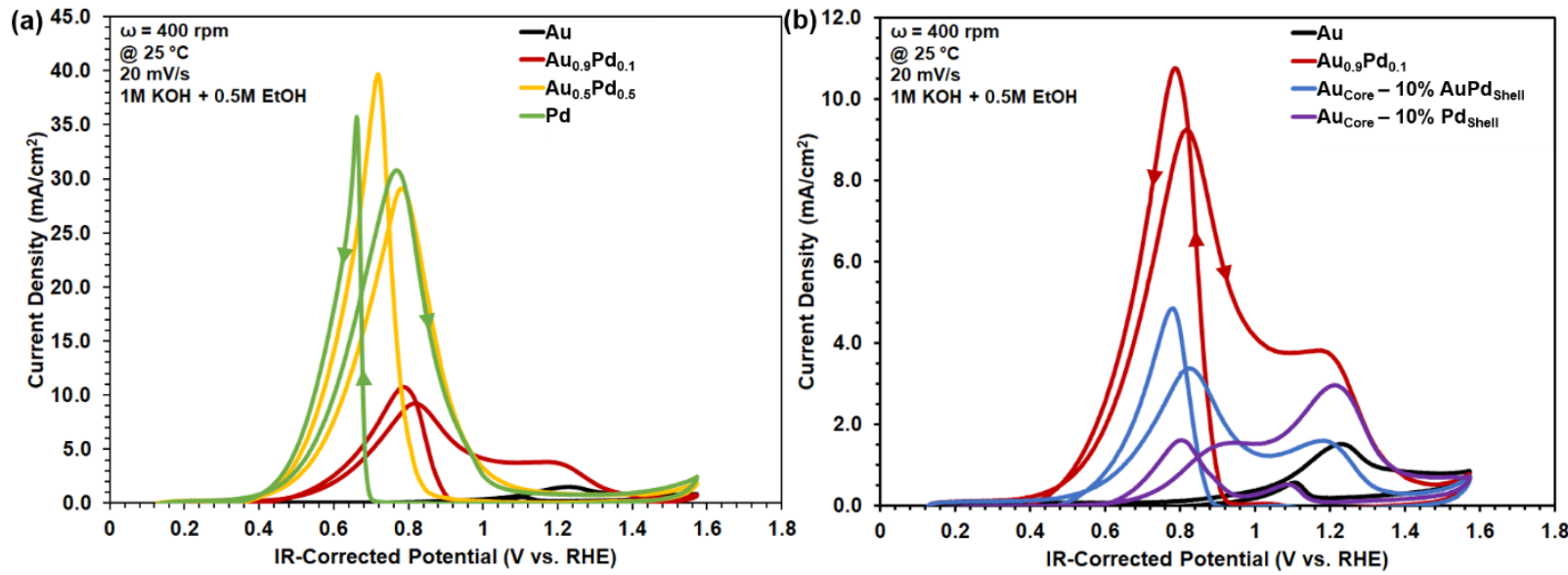

Figure 7. Electrochemical CVs for EtOH oxidation catalyzed by 20 wt.\% (a) $\mathrm{Au}_{1-x} \mathrm{Pd}_{x}$ and (b) $\mathrm{Au}_{\mathrm{Core}}-\mathrm{Au}_{1-x} \mathrm{Pd}_{x} \cdot \mathrm{Shell}_{\mathrm{NPs}}$ dispersed on carbon supports deposited onto a rotating disk, glassy carbon working electrode. Reference and counter electrodes were $\mathrm{Ag} / \mathrm{AgCl}$ and a $\mathrm{Pt}$ coil, respectively, immersed in $0.5 \mathrm{M} \mathrm{EtOH}$ with $1 \mathrm{M} \mathrm{KOH}$ supporting electrolyte. 
Table 3. Electrochemical onset potentials, peak potentials, and peak current densities for forward and reverse CV scans of the $\mathrm{Au}_{1-x} \mathrm{Pd}_{x}$ and $\mathrm{Au}_{\text {Core }}-\mathrm{Au}_{1-x} \mathrm{Pd}_{x}$.Shell NPs on carbon supports in the dark.

\begin{tabular}{|c|c|c|c|c|c|}
\hline Composition & Onset (V) & $V_{F}(V)$ & $I_{F}\left(\mathrm{~mA} / \mathrm{cm}^{2}\right)$ & $V_{R}(V)$ & $\mathrm{I}_{\mathrm{R}}\left(\mathrm{mA} / \mathrm{cm}^{2}\right)$ \\
\hline $\mathrm{Au}$ & 0.72 & 1.23 & 1.51 & 1.10 & 0.56 \\
\hline \multirow[t]{2}{*}{$\mathrm{Au}_{0.9} \mathrm{Pd}_{0.1}$} & 0.35 & 0.82 & 9.26 & 0.79 & 10.75 \\
\hline & & 1.17 & 3.81 & 1.03 & 0.04 \\
\hline $\mathrm{AuPd}$ & 0.32 & 0.79 & 29.14 & 0.66 & 35.74 \\
\hline $\mathrm{Pd}$ & 0.30 & 0.77 & 30.80 & 0.66 & 35.74 \\
\hline \multirow[t]{2}{*}{$\mathrm{Au}-10 \% \mathrm{AuPd}$} & 0.40 & 0.82 & 3.37 & 0.78 & 4.85 \\
\hline & & 1.18 & 1.60 & & \\
\hline \multirow[t]{2}{*}{$\mathrm{Au}-10 \% \mathrm{Pd}$} & 0.52 & 0.94 & 1.55 & 0.80 & 1.61 \\
\hline & & 1.21 & 2.96 & 1.08 & 0.52 \\
\hline
\end{tabular}

\subsection{Photoelectrochemical Ethanol Oxidation via Au-Pd NPs on $\mathrm{TiO}_{2}$ Supports}

The selected $\mathrm{Au}_{1-x} \mathrm{Pd}_{x}$ alloys and $\mathrm{Au}_{\text {Core }}-\mathrm{Au}_{1-x} \mathrm{Pd}_{x}$.Shell NPs were further investigated by $\mathrm{CV}$ and chronoamperometry (CA) for their SPR-induced photoelectrochemical (PEC) EOR by photosensitizing $\mathrm{TiO}_{2}$ supports. $\mathrm{CV}$ scans in the dark and under AM1.5G irradiation are shown in Supplementary Figures S10-S12. Catalytic metals like Pt and Pd enhance the extraction and use of plasmonic carriers generated in $\mathrm{Au}[4,18,20,28,29,43,53,54]$. Furthermore, hot electron transfer and photothermal processes can facilitate intermediate removal during irradiation $[3,5,9]$. Elucidation of the role of SPR effects on EOR motivated solar-simulated CA photocurrent studies. Plasmon-enhanced EOR photocurrents were measured via CA scans on a RDE immersed in $0.5 \mathrm{M}$ EtOH (1 M KOH supporting electrolyte, $25^{\circ} \mathrm{C}$ ) for current density (Figure $8 \mathrm{a}$ ) and mass activity (Figure $8 \mathrm{~b}$ ) measurements. CA measurements were held at a bias of appreciable current (+0.72 V vs. RHE), with $250 \mathrm{~s}$ on/off chopping of broadband AM1.5G irradiation. Applied potential improves electron transport to the back contact and decreases the surface recombination rate, while demonstrating appreciable EOR current for both alloy and core-shell compositions of interest. Analyses focus on the average photocurrent magnitude measured during the first "light on" step and after $1900 \mathrm{~s}$ chopped irradiance, as shown in Figure 8 and in Supplementary Tables S4 and S5.
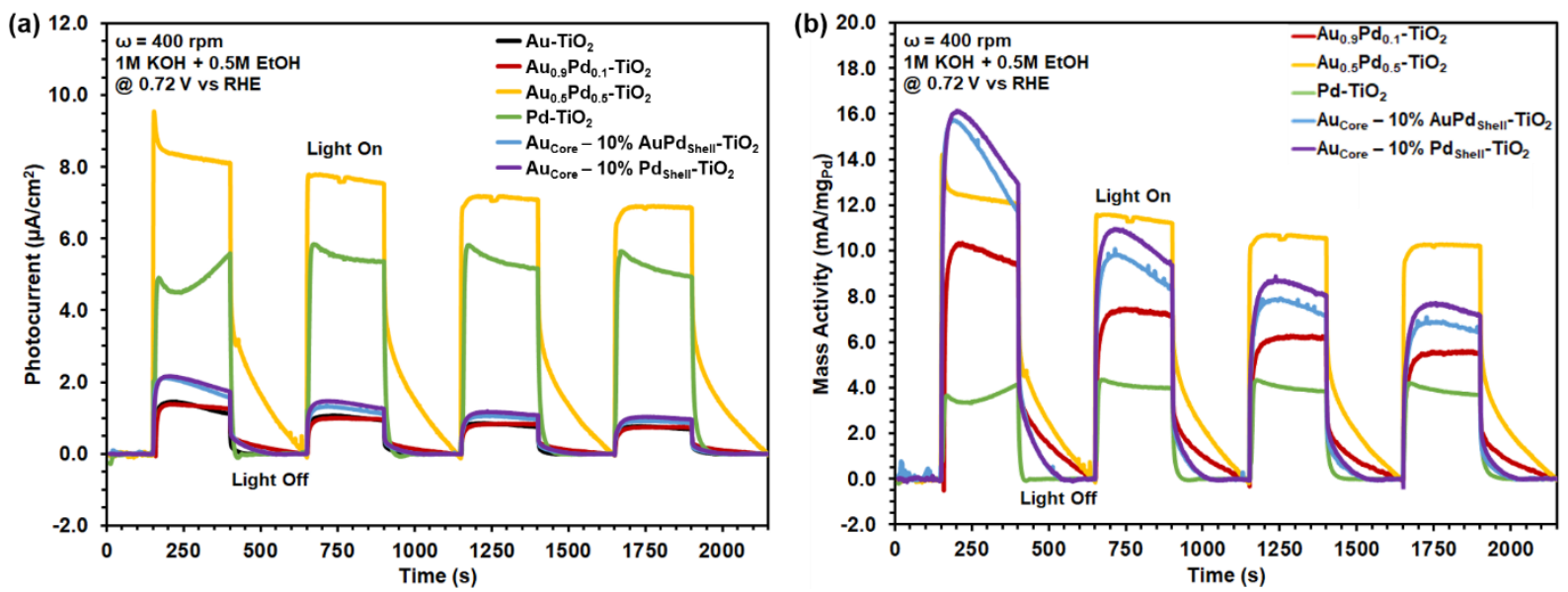

Figure 8. Photoelectrochemical chronoamperometry for EtOH oxidation catalyzed by 1 wt.\% $\mathrm{Au}_{1-x} \mathrm{Pd}_{x}$ and $\mathrm{Au}_{\mathrm{Core}}{ }^{-}$ $\mathrm{Au}_{1-x} \mathrm{Pd}_{x}$.Shell NPs dispersed on $\mathrm{TiO}_{2}$ deposited onto a rotating disk, glassy carbon working electrode. Reference and counter electrodes were $\mathrm{Ag} / \mathrm{AgCl}$ and a Pt coil, respectively, immersed in $0.5 \mathrm{M} \mathrm{EtOH}$ with $1 \mathrm{M} \mathrm{KOH}$ supporting electrolyte. Photo-induced (a) current densities and (b) mass activities held at $+0.72 \mathrm{~V}$ (vs. RHE) under $250 \mathrm{~s}$ on/off chopping of solar-simulated AM1.5G irradiation. The baseline (i.e., $0 \mu \mathrm{A} \mathrm{cm}^{-2}$ ) is the dark current.

Immediate photocurrent response resulted from the separation of photogenerated electron-hole pairs at the electrode-electrolyte interface. Anodic (positive) spikes in pho- 
tocurrent indicated accumulation of charge at the electrode-electrolyte interface, while cathodic (negative) transients are indicative of charge recombination. Lack of photocurrent transients indicated unimpeded charge transfer from the electrode to the electrolyte, thereby hole transfer was facilitated at the catalyst surface for EOR [55-57]. Average peak EOR photocurrent densities generated under AM1.5G irradiation on $\mathrm{TiO}_{2}$ in Figure 8a were $1.31 \mu \mathrm{A}$ $\mathrm{cm}^{-2}$ for $\mathrm{Au}, 1.31 \mu \mathrm{A} \mathrm{cm}^{-2}$ for $\mathrm{Au}_{0.9} \mathrm{Pd}_{0.1}, 1.43 \mu \mathrm{A} \mathrm{cm}^{-2}$ for $\mathrm{Au}_{\text {Core }}-\mathrm{AuPd}_{\text {Shell }}$, and $1.97 \mu \mathrm{A}$ $\mathrm{cm}^{-2}$ for $\mathrm{Au}_{\text {Core }}-\mathrm{Pd}_{\text {Shell }}$. Notably, no photo-induced current enhancement was observed for Au-Pd alloy thin films absent of SPR effects in our previous studies [30]. Au-Pd photosensitized samples were reactivated by successive CV scans to remove surface-adsorbed intermediates. Au-rich compositions $\left(\mathrm{Au}, \mathrm{Au}_{0.9} \mathrm{Pd}_{0.1}, \mathrm{Au}_{\text {Core }}-\mathrm{AuPd}_{\text {Shell }}, \mathrm{Au}_{\text {Core }}-\mathrm{Pd}_{\text {Shell }}\right)$ act as hole accumulation sites, creating a positively charged surface to promote the adsorption of electron donors such as EtOH [11,12]. However, interband transitions that occur at shorter wavelengths $(\lambda<600 \mathrm{~nm})$ between filled $d$-band and empty $s p$-states dominate for Au-rich NP compositions, resulting primarily in $2 \mathrm{e}^{-}$products rather than complete oxidation [6,11,12]. Appreciable loss in photocurrent during sustained bias holds was observed overtime for all Au-Pd photosensitized samples with photocurrent retention of $47 \%$ for $\mathrm{Au}, 53 \%$ for $\mathrm{Au}_{0.9} \mathrm{Pd}_{0.1}, 40 \%$ for $\mathrm{Au}_{\text {Core }}-\mathrm{AuPd}_{\text {Shell }}$, and $44 \%$ for $\mathrm{Au}_{\text {Core }}-\mathrm{Pd}_{\text {Shell }}$ on $\mathrm{TiO}_{2}$ after $1900 \mathrm{~s}$ at the sustained bias (0.72 V vs. RHE). Relatively low photocurrents for Au-rich compositions suggest that some excited carriers on the cocatalysts relax via electron-phonon scattering, thereby increasing the surface temperature. While photothermal heating can contribute to photocatalytic activity and gaseous product yields (Figure 6), higher rates of hot-carrier separation and transfer in Au-rich compositions are necessary for increased photocurrents (Figure 8).

Alloying $\geq 50 \%$ Pd with Au had the largest impact on the EOR photocurrent, with a photocurrent density of $8.32 \mu \mathrm{A} \mathrm{cm}^{-2}$ for AuPd alloy on $\mathrm{TiO}_{2}$. Notably, AuPd alloy on $\mathrm{TiO}_{2}$ retained $72 \%$ of its initial photocurrent after $1900 \mathrm{~s}$ at the sustained bias. Alloying $\mathrm{Au}$ with $\mathrm{Pd}$ resulted in an even distribution of metal active sites for reactant binding; reducing the stability of the intermediate and improving activity [58]. The increase in photocurrent was attributed to interband excitations that initiated injection of $d$-band holes from the Au into the Pd active sites for subsequent reaction with adsorbed species [59]. Slow relaxation of the photocurrent after the "light on" step for AuPd alloy indicated accumulation of holes at the electrode-electrolyte interface, facilitated favorable reaction kinetics, and hindered charge recombination [55-57]. In comparison, catalytic $\mathrm{Pd}$ on $\mathrm{TiO}_{2}$ generated $4.74 \mu \mathrm{A} \mathrm{cm}{ }^{-2}$ and retained $84 \%$ of its initial photocurrent after $1900 \mathrm{~s}$ owing to Pd acting as a hole scavenger, which improved charge separation at the metal-semiconductor interface. Average photo-enhancement in terms of mass activity $\left(\mathrm{mA} / \mathrm{mg}_{\mathrm{Pd}}\right)$ in Figure $8 \mathrm{~b}$ showed a moderate improvement for core-shell NPs $\left(10.60-14.70 \mathrm{~mA} / \mathrm{mg}_{\mathrm{Pd}}\right)$ in comparison to the analogous alloy composition of $\mathrm{Au}_{0.9} \mathrm{Pd}_{0.1}(9.76 \mathrm{~mA} / \mathrm{mg} \mathrm{Pd})$. Photocurrent enhancements were observed for all bimetallic Au-Pd compositions (9.76-14.70 mA/mg $\mathrm{Pd}$ ) compared to pure $\mathrm{Pd}$ $\left(3.53 \mathrm{~mA} / \mathrm{mg}_{\mathrm{Pd}}\right)$. Initially, core-shell NPs exhibited high mass activity performance at the first "light on" step but rapidly decayed. AuPd (1:1 mole ratio) alloy retained the highest mass activity (10.20 mA/mg $/ \mathrm{mg}_{\text {Pd }}$ ) after 1900s compared to all measured compositions and nanostructured catalysts. Bimetallic AuPd alloy catalysts exhibited the ability to selectively drive photochemical and PEC reactions at improved efficiency with the assistance of their SPR and ligand effects.

\section{Conclusions}

Bimetallic Au-Pd NPs were synthetically modified to influence the plasmonic nearfield enhancement, optical absorption, and catalytic activity resultant from PMET and photothermal effects. TEM imaging and elemental analysis confirmed the composition and nanostructuring (alloy vs. core-shell). XPS revealed a shift in $d$-band onset toward the $\mathrm{E}_{\mathrm{F}}$ and an increase in the DOS at the $\mathrm{E}_{\mathrm{F}}$ with an increase in Pd content. Modifying the $\mathrm{Au}-\mathrm{Pd}$ composition provides atomic control over tuning the ligand effect to impact reactant adsorption to the catalyst surface, and thereby the catalytic activity. UV-vis 
spectroscopy revealed the plasmonic response was retained and appreciable for alloys containing $\geq 50 \% \mathrm{Au}$ and core-shell nanostructures with intact plasmonic Au cores. Au$\mathrm{Pd}$ alloys and core-shells exhibited $\mathrm{E}_{\mathrm{F}}$ below the $\mathrm{CB}$ of $\mathrm{TiO}_{2}$, as confirmed by XPS, and the composites maintained their SPR effect that progressively blue-shifted with increasing $\mathrm{Pd}$, as confirmed by UV-Vis DRS. DDA simulations of the spatial distributions of the electric field enhancement showed pure Au exhibited the strongest SPR response, with $\mathrm{AuPd}$ and Pd exhibiting similar intensity responses, localized at the metal-semiconductor interface. Photocatalytic and electrochemical oxidation of $\mathrm{EtOH}$ to $\mathrm{CO}_{2}$ under dark and solar-simulated irradiation was studied, with a focus on product selectivity, $\mathrm{C}-\mathrm{C}$ bond breaking, and mitigating catalyst poisoning. Supported AuPd (1:1 mole ratio) alloy yielded optimal photocatalytic $(456 \mu \mathrm{mol} \mathrm{CO} 2 / \mathrm{g})$, electrochemical $\left(29.14 \mathrm{~mA} \cdot \mathrm{cm}^{-2}\right)$, and PEC $\left(8.32 \mu \mathrm{A} \mathrm{cm}^{-2}\right)$ results owing to metallic effects (plasmonic, catalytic, ligand effects) and atomically distributed $\mathrm{Au}$ and $\mathrm{Pd}$ surface active sites to inhibit side reactions and poisoning. The AuPd alloy was found to be the ideal composition and nanostructured bimetallic for complete EtOH conversion. Photogenerated holes drive the photo-oxidation of $\mathrm{EtOH}$ primarily on the AuPd alloy and photothermal effects improve intermediate desorption from the catalyst surface, providing a method to selectively cleave $\mathrm{C}-\mathrm{C}$ bonds. Plasmonic bimetallic nanostructures provide a pathway for driving desired photocatalytic and PEC reactions with superior catalytic activity and selectivity.

Supplementary Materials: The following are available online at https://www.mdpi.com/2073-4 352/11/3/226/s1, Figure S1 and S2: EDXS, Figure S3: XPS survey scans, Figure S4: XPS scans of the VB region, Figure S5 and S6: UV-Vis extinction spectra, Figure S7: UV-Vis DRS, Figure S8: DDA simulated absorption spectra, Figure S9 and S10: Electrochemical CVs in $1 \mathrm{M} \mathrm{KOH}$, Figure S11 and S12: Electrochemical CVs of EtOH oxidation, Table S1: Experimental and DDA calculated SPR peaks, Tables S2 and S3: Photocatalytic mass activities, Table S4: Photo-induced current densities, Table S5: Photo-induced mass activities.

Author Contributions: Conceptualization, methodology, investigation, writing—original draft preparation, J.B.; electron microscopy, A.C.L.; numerical computation, G.T.F.; X-ray photoelectron spectroscopy, D.R.B.; writing—review and editing, J.B., A.C.L., G.T.F., and D.R.B.; supervision, D.R.B. All authors have read and agreed to the published version of the manuscript.

Funding: This work was sponsored by DEVCOM-Army Research Laboratory.

Data Availability Statement: Data is contained within the article or supplementary material.

Acknowledgments: The views and conclusions contained in this document are those of the authors and should not be interpreted as representing official policies, either expressed or implied, of the DEVCOM-Army Research Laboratory or the U.S. Government. The U.S. Government is authorized to reproduce and distribute reprints for government purposes notwithstanding any copyright notation herein.

Conflicts of Interest: The authors declare no conflict of interest.

\footnotetext{
Abbreviations

$\mathrm{Au}$, gold; Pd, palladium; NPs, nanoparticles; SPR, surface plasmon resonance; EtOH, ethanol; EOR, ethanol oxidation reaction; $\mathrm{C}-\mathrm{C}$, carbon-carbon bond; $\mathrm{PEC}$, photoelectrochemistry; DDA, discrete dipole approximation; UV-Vis, ultraviolet-visible; NIR, near-infrared; XPS, X-ray photoelectron spectroscopy; EDXS, energy-dispersive X-ray spectroscopy; HAADF-STEM, high-angle annular dark-field imaging scanning transmission electron microscopy; STEM, scanning transmission electron microscopy; TEM, transmission electron microscopy; GC-MS-MHE, gas chromatography-mass spectrometry-multiple headspace extraction; RDE, rotating disk electrode; RHE, reversible hydrogen electrode; $\mathrm{CV}$, cyclic voltammetry; $\mathrm{CA}$, chronoamperometry; $\mathrm{VB}$, valence band; $\mathrm{CB}$, conduction band; DOS, density of states; DFT, density functional theory; PMET, plasmon-mediated hot electron transfer.
} 


\section{References}

1. Wang, M.; Ma, J.; Liu, H.; Luo, N.; Zhao, Z.; Wang, F. Sustainable Productions of Organic Acids and Their Derivatives from Biomass via Selective Oxidative Cleavage of C-C Bond. ACS Catal. 2018, 8, 2129-2165. [CrossRef]

2. Lamy, C.; Belgsir, E.M.; Léger, J.M. Electrocatalytic Oxidation of Aliphatic Alcohols: Application to the Direct Alcohol Fuel Cell (DAFC). J. Appl. Electrochem. 2001, 31, 799-809. [CrossRef]

3. Zhang, Y.; He, S.; Guo, W.; Hu, Y.; Huang, J.; Mulcahy, J.R.; Wei, W.D. Surface-Plasmon-Driven Hot Electron Photochemistry. Chem. Rev. 2018, 118, 2927-2954. [CrossRef]

4. Ortiz, N.; Zoellner, B.; Hong, S.J.; Ji, Y.; Wang, T.; Liu, Y.; Maggard, P.A.; Wang, G. Harnessing Hot Electrons from Near IR Light for Hydrogen Production Using Pt-End-Capped-AuNRs. ACS Appl. Mater. Interfaces 2017, 9, 25962-25969. [CrossRef] [PubMed]

5. Boltersdorf, J.; Leff, A.C.; Forcherio, G.T.; McClure, J.P.; Lundgren, C.A. Surface Plasmon Resonant Gold-Palladium Bimetallic Nanoparticles for Promoting Catalytic Oxidation. MRS Adv. 2019, 4, 1877-1886. [CrossRef]

6. Boltersdorf, J.; Forcherio, G.T.; McClure, J.P.; Baker, D.R.; Leff, A.C.; Lundgren, C. Visible Light-Promoted Plasmon Resonance to Induce "Hot" Hole Transfer and Photothermal Conversion for Catalytic Oxidation. J. Phys. Chem. C 2018, 122, 28934-28948. [CrossRef]

7. McClure, J.P.; Grew, K.N.; Baker, D.R.; Gobrogge, E.; Das, N.; Chu, D. Harvesting Resonantly-Trapped Light for Small Molecule Oxidation Reactions at the $\mathrm{Au} / \alpha-\mathrm{Fe}_{2} \mathrm{O}_{3}$ Interface. Nanoscale 2018, 10, 7833-7850. [CrossRef]

8. Jain, P.K. Taking the Heat off of Plasmonic Chemistry. J. Phys. Chem. C 2019, 123, 24347-24351. [CrossRef]

9. Qiu, J.; Wei, W.D. Surface Plasmon-Mediated Photothermal Chemistry. J. Phys. Chem. C 2014, 118, 20735-20749. [CrossRef]

10. Kim, S.M.; Lee, S.W.; Moon, S.Y.; Park, J.Y. The Effect of Hot Electrons and Surface Plasmons on Heterogeneous Catalysis. J. Phys. Condens. Matter 2016, 28, 254002. [CrossRef]

11. Tan, T.H.; Scott, J.; Ng, Y.H.; Taylor, R.A.; Aguey-Zinsou, K.F.; Amal, R. Understanding Plasmon and Band Gap Photoexcitation Effects on the Thermal-Catalytic Oxidation of Ethanol by $\mathrm{TiO}_{2}$-Supported Gold. ACS Catal. 2016, 6, 1870-1879. [CrossRef]

12. Tan, T.H.; Scott, J.; Ng, Y.H.; Taylor, R.A.; Aguey-Zinsou, K.F.; Amal, R. C-C Cleavage by Au/TiO 2 during Ethanol Oxidation: Understanding Bandgap Photoexcitation and Plasmonically Mediated Charge Transfer via Quantitative in Situ DRIFTS. ACS Catal. 2016, 6, 8021-8029. [CrossRef]

13. Li, K.; Hogan, N.J.; Kale, M.J.; Halas, N.J.; Nordlander, P.; Christopher, P. Balancing Near-Field Enhancement, Absorption, and Scattering for Effective Antenna-Reactor Plasmonic Photocatalysis. Nano Lett. 2017, 17, 3710-3717. [CrossRef] [PubMed]

14. Kumar, P.V.; Norris, D.J. Tailoring Energy Transfer from Hot Electrons to Adsorbate Vibrations for Plasmon-Enhanced Catalysis. ACS Catal. 2017, 7, 8343-8350. [CrossRef]

15. Jovic, V.; Chen, W.-T.; Sun-Waterhouse, D.; Blackford, M.G.; Idriss, H.; Waterhouse, G.I.N. Effect of Gold Loading and TiO 2 Support Composition on the Activity of $\mathrm{Au} / \mathrm{TiO}_{2}$ Photocatalysts for $\mathrm{H}_{2}$ Production from Ethanol-Water Mixtures. J. Catal. 2013, 305, 307-317. [CrossRef]

16. Guo, J.; Zhang, Y.; Shi, L.; Zhu, Y.; Mideksa, M.F.; Hou, K.; Zhao, W.; Wang, D.; Zhao, M.; Zhang, X.; et al. Boosting Hot Electrons in Hetero-Superstructures for Plasmon-Enhanced Catalysis. J. Am. Chem. Soc. 2017, 139, 17964-17972. [CrossRef]

17. Joplin, A.; Hosseini Jebeli, S.A.; Sung, E.; Diemler, N.; Straney, P.J.; Yorulmaz, M.; Chang, W.S.; Millstone, J.E.; Link, S. Correlated Absorption and Scattering Spectroscopy of Individual Platinum-Decorated Gold Nanorods Reveals Strong Excitation Enhancement in the Nonplasmonic Metal. ACS Nano 2017, 11, 12346-12357. [CrossRef]

18. Sytwu, K.; Vadai, M.; Dionne, J.A. Bimetallic Nanostructures: Combining Plasmonic and Catalytic Metals for Photocatalysis. Adv. Phys. X 2019, 4, 389-422. [CrossRef]

19. Zheng, Z.; Xie, W.; Li, M.; Ng, Y.H.; Wang, D.W.; Dai, Y.; Huang, B.; Amal, R. Platinum Electrocatalysts with Plasmonic Nano-Cores for Photo-Enhanced Oxygen-Reduction. Nano Energy 2017, 41, 233-242. [CrossRef]

20. Zheng, Z.; Tachikawa, T.; Majima, T. Plasmon-Enhanced Formic Acid Dehydrogenation Using Anisotropic Pd-Au Nanorods Studied at the Single-Particle Level. J. Am. Chem. Soc. 2015, 137, 948-957. [CrossRef]

21. Zheng, Z.; Tachikawa, T.; Majima, T. Single-Particle Study of Pt-Modified Au Nanorods for Plasmon-Enhanced Hydrogen Generation in Visible to near-Infrared Region. J. Am. Chem. Soc. 2014, 136, 6870-6873. [CrossRef]

22. Koelling, D.; Freeman, A.; Mueller, F.; Johnson, P.B.; Christy, R.W. Optical Constants of the Noble Metals. Phys. Rev. B 1963, 11. [CrossRef]

23. Olson, J.; Dominguez-Medina, S.; Hoggard, A.; Wang, L.Y.; Chang, W.S.; Link, S. Optical Characterization of Single Plasmonic Nanoparticles. Chem. Soc. Rev. 2015, 44, 40-57. [CrossRef] [PubMed]

24. Hartland, G.V. Optical Studies of Dynamics in Noble Metal Nanostructures. Chem. Rev. 2011, 111, 3858-3887. [CrossRef]

25. Liang, Z.X.; Zhao, T.S.; Xu, J.B.; Zhu, L.D. Mechanism Study of the Ethanol Oxidation Reaction on Palladium in Alkaline Media. Electrochim. Acta 2009, 54, 2203-2208. [CrossRef]

26. Fan, F.R.; Liu, D.Y.; Wu, Y.F.; Duan, S.; Xie, Z.X.; Jiang, Z.Y.; Tian, Z.Q. Epitaxial Growth of Heterogeneous Metal Nanocrystals: From Gold Nano-Octahedra to Palladium and Silver Nanocubes. J. Am. Chem. Soc. 2008, 130, 6949-6951. [CrossRef] [PubMed]

27. Dejarnette, D.; Roper, D.K. Electron Energy Loss Spectroscopy of Gold Nanoparticles on Graphene. J. Appl. Phys. 2014, 116, 054313. [CrossRef]

28. Forcherio, G.T.; Baker, D.R.; Leff, A.C.; Boltersdorf, J.; McClure, J.P.; Grew, K.N.; Lundgren, C.A. Photodeposition of Pd onto Colloidal Au Nanorods by Surface Plasmon Excitation. J. Vis. Exp. 2019, 2019, 6-11. [CrossRef] [PubMed] 
29. Forcherio, G.T.; Baker, D.R.; Boltersdorf, J.; Leff, A.C.; McClure, J.P.; Grew, K.N.; Lundgren, C.A. Targeted Deposition of Platinum onto Gold Nanorods by Plasmonic Hot Electrons. J. Phys. Chem. C 2018, 122, 28901-28909. [CrossRef]

30. McClure, J.P.; Boltersdorf, J.; Baker, D.R.; Farinha, T.G.; Dzuricky, N.; Villegas, C.E.P.; Rocha, A.R.; Leite, M.S. Structure-PropertyPerformance Relationship of Ultrathin Pd-Au Alloy Catalyst Layers for Low-Temperature Ethanol Oxidation in Alkaline Media. ACS Appl. Mater. Interfaces 2019, 11, 24919-24932. [CrossRef]

31. Monyoncho, E.A.; Steinmann, S.N.; Michel, C.; Baranova, E.A.; Woo, T.K.; Sautet, P. Ethanol Electro-Oxidation on Palladium Revisited Using Polarization Modulation Infrared Reflection Absorption Spectroscopy (PM-IRRAS) and Density Functional Theory (DFT): Why Is It Difficult to Break the C-C Bond? ACS Catal. 2016, 6, 4894-4906. [CrossRef]

32. Lai, S.C.S.; Kleijn, S.E.F.; Öztürk, F.T.Z.; Van Rees Vellinga, V.C.; Koning, J.; Rodriguez, P.; Koper, M.T.M. Effects of Electrolyte PH and Composition on the Ethanol Electro-Oxidation Reaction. Catal. Today 2010, 154, 92-104. [CrossRef]

33. Kwon, Y.; Lai, S.C.S.; Rodriguez, P.; Koper, M.T.M. Electrocatalytic Oxidation of Alcohols on Gold in Alkaline Media: Base or Gold Catalysis? J. Am. Chem. Soc. 2011, 133, 6914-6917. [CrossRef] [PubMed]

34. Wang, Y.; Zou, S.; Cai, W. Bin Recent Advances on Electro-Oxidation of Ethanol on Pt- and Pd-Based Catalysts: From Reaction Mechanisms to Catalytic Materials. Catalysts 2015, 5, 1507-1534. [CrossRef]

35. Kadkhodazadeh, S.; Anggoro Ardy Nugroho, F.; Langhammer, C.; Beleggia, M.; Wagner, J.B. Optical Property-Composition Correlation in Noble Metal Alloy Nanoparticles Studied with EELS. ACS Photonics 2019, 6, 779-786. [CrossRef]

36. Hoggard, A.; Wang, L.Y.; Ma, L.; Fang, Y.; You, G.; Olson, J.; Liu, Z.; Chang, W.S.; Ajayan, P.M.; Link, S. Using the Plasmon Linewidth to Calculate the Time and Efficiency of Electron Transfer between Gold Nanorods and Graphene. ACS Nano 2013, 7, 11209-11217. [CrossRef] [PubMed]

37. Draine, B.T.; Flatau, P.J. Discrete-Dipole Approximation for Scattering Calculations. J. Opt. Soc. Am. A 1994, 11, 1491-1499. [CrossRef]

38. Flatau, P.J.; Draine, B.T. Fast near Field Calculations in the Discrete Dipole Approximation for Regular Rectilinear Grids. Opt. Express 2012, 20, 1247-1252. [CrossRef]

39. Draine, B.T.; Flatau, P.J. Discrete-Dipole Approximation for Periodic Targets: Theory and Tests. J. Opt. Soc. Am. A 2008, 25, 2693. [CrossRef]

40. Forcherio, G.T.; Boltersdorf, J.; McClure, J.P.; Leff, A.C.; Baker, D.R.; Lundgren, C.A. Directed Assembly of Bimetallic Nanoarchitectures by Interfacial Photocatalysis with Plasmonic Hot Electrons. In Nanophotonic Materials XV; International Society for Optics and Photonics: Bellingham, WA, USA, 2018; p. 19. [CrossRef]

41. Xinyin, S.; Frankel, D.J.; Hermanson, J.C.; Lapeyre, G.J.; Smith, R.J. Photoemission Studies of Ordered Pd Overlayers on Au(111): Implications for CO Chemisorption. Phys. Rev. B 1985, 32, 2120-2125. [CrossRef] [PubMed]

42. Bligaard, T.; Nørskov, J.K. Ligand Effects in Heterogeneous Catalysis and Electrochemistry. Electrochim. Acta 2007, 52, 5512-5516. [CrossRef]

43. Su, R.; Tiruvalam, R.; Logsdail, A.J.; He, Q.; Downing, C.A.; Jensen, M.T.; Dimitratos, N.; Kesavan, L.; Wells, P.P.; Bechstein, R.; et al. Designer Titania-Supported Au-Pd Nanoparticles for Efficient Photocatalytic Hydrogen Production. ACS Nano 2014, 8 , 3490-3497. [CrossRef]

44. Foerster, B.; Joplin, A.; Kaefer, K.; Celiksoy, S.; Link, S.; Sönnichsen, C. Chemical Interface Damping Depends on Electrons Reaching the Surface. ACS Nano 2017, 11, 2886-2893. [CrossRef]

45. Forcherio, G.T.; Dunklin, J.R.; Backes, C.; Vaynzof, Y.; Benamara, M.; Roper, D.K. Gold Nanoparticles Physicochemically Bonded onto Tungsten Disulfide Nanosheet Edges Exhibit Augmented Plasmon Damping. AIP Adv. 2017, 7, 075103. [CrossRef]

46. Boltersdorf, J.; King, N.; Maggard, P.A. Flux-Mediated Crystal Growth of Metal Oxides: Synthetic Tunability of Particle Morphologies, Sizes, and Surface Features for Photocatalysis Research. CrystEngComm 2015, 17, 2225-2241. [CrossRef]

47. Gao, F.; Goodman, D.W. Pd-Au Bimetallic Catalysts: Understanding Alloy Effects from Planar Models and (Supported) Nanoparticles. Chem. Soc. Rev. 2012, 41, 8009-8020. [CrossRef] [PubMed]

48. Lee, Y.W.; Kim, M.; Kim, Y.; Kang, S.W.; Lee, J.H.; Han, S.W. Synthesis and Electrocatalytic Activity of Au-Pd Alloy Nanodendrites for Ethanol Oxidation. J. Phys. Chem. C 2010, 114, 7689-7693. [CrossRef]

49. Wang, B.; Tao, L.; Cheng, Y.; Yang, F.; Jin, Y.; Zhou, C.; Yu, H.; Yang, Y. Electrocatalytic Oxidation of Small Molecule Alcohols over $\mathrm{Pt}, \mathrm{Pd}$, and Au Catalysts: The Effect of Alcohol's Hydrogen Bond Donation Ability and Molecular Structure Properties. Catalysts 2019, 9, 387. [CrossRef]

50. Song, H.M.; Anjum, D.H.; Sougrat, R.; Hedhili, M.N.; Khashab, N.M. Hollow Au@Pd and Au@Pt Core-Shell Nanoparticles as Electrocatalysts for Ethanol Oxidation Reactions. J. Mater. Chem. 2012, 22, 25003-25010. [CrossRef]

51. Ksar, F.; Ramos, L.; Keita, B.; Nadjo, L.; Beaunier, P.; Remita, H. Bimetallic Palladium-Gold Nanostructures: Application in Ethanol Oxidation. Chem. Mater. 2009, 21, 3677-3683. [CrossRef]

52. Zhu, L.D.; Zhao, T.S.; Xu, J.B.; Liang, Z.X. Preparation and Characterization of Carbon-Supported Sub-Monolayer Palladium Decorated Gold Nanoparticles for the Electro-Oxidation of Ethanol in Alkaline Media. J. Power Sources 2009, 187, 80-84. [CrossRef]

53. Li, Y.; Hu, J.; Ma, D.; Zheng, Y.; Chen, M.; Wan, H. Disclosure of the Surface Composition of TiO ${ }_{2}$-Supported Gold-Palladium Bimetallic Catalysts by High-Sensitivity Low-Energy Ion Scattering Spectroscopy. ACS Catal. 2018, 8, 1790-1795. [CrossRef]

54. Engelbrekt, C.; Crampton, K.T.; Fishman, D.A.; Law, M.; Apkarian, V.A. Efficient Plasmon-Mediated Energy Funneling to the Surface of Au@Pt Core-Shell Nanocrystals. ACS Nano 2020, 14, 5061-5074. [CrossRef] [PubMed] 


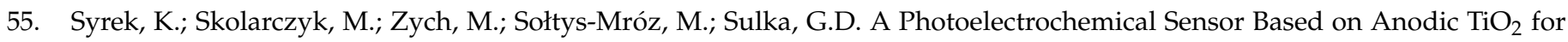
Glucose Determination. Sensors 2019, 19, 4981. [CrossRef] [PubMed]

56. Dumortier, M.; Bosserez, T.; Rongé, J.; Martens, J.A.; Haussener, S. Combined Experimental-Numerical Analysis of Transient Phenomena in a Photoelectrochemical Water Splitting Cell. J. Phys. Chem. C 2016, 120, 3705-3714. [CrossRef]

57. Gurudayal, G.; Chiam, S.Y.; Kumar, M.H.; Bassi, P.S.; Seng, H.L.; Barber, J.; Wong, L.H. Improving the Efficiency of Hematite Nanorods for Photoelectrochemical Water Splitting by Doping with Manganese. ACS Appl. Mater. Interfaces 2014, 6, 5852-5859. [CrossRef]

58. Molina, L.M.; Benito, A.; Alonso, J.A. Ab Initio Studies of Ethanol Dehydrogenation at Binary AuPd Nanocatalysts. Mol. Catal. 2018, 449, 8-13. [CrossRef]

59. Al-Zubeidi, A.; Hoener, B.S.; Collins, S.S.E.; Wang, W.; Kirchner, S.R.; Hosseini Jebeli, S.A.; Joplin, A.; Chang, W.S.; Link, S.; Landes, C.F. Hot Holes Assist Plasmonic Nanoelectrode Dissolution. Nano Lett. 2019, 19, 1301-1306. [CrossRef] [PubMed] 